LBL-33194

UC 350

\title{
Hydronic Radiant Cooling Overview and Preliminary Performance Assessment
}

\author{
Helmut E. Feustel
}

\author{
Energy and Environment Division \\ Lawrence Berkeley Laboratory \\ Berkeley, CA 94720 \\ Indoor Environment Program \\ Lawrence Berkeley Laboratory \\ Berkeley, CA 94720
}

May 1993

This work was jointly supported by the California Institute for Energy Efficiency and by the Assistant Secretary for Consenation and Renewable Energy, Office of Building Energy Research and Development, Building Systems Division of the U.S. Department of Energy under Contract No. DE-AC03-76SF00098 
LBL-33194

UC 350

\title{
Hydronic Radiant Cooling Overview and Preliminary Performance Assessment
}

\author{
Helmut E. Feustel \\ Lawrence Berkeley Laboratory \\ Energy and Environment Division \\ Indoor Environment Program \\ Energy Performance of Buildings Group \\ Berkeley, CA 94720
}

May 1993

\section{Contents}

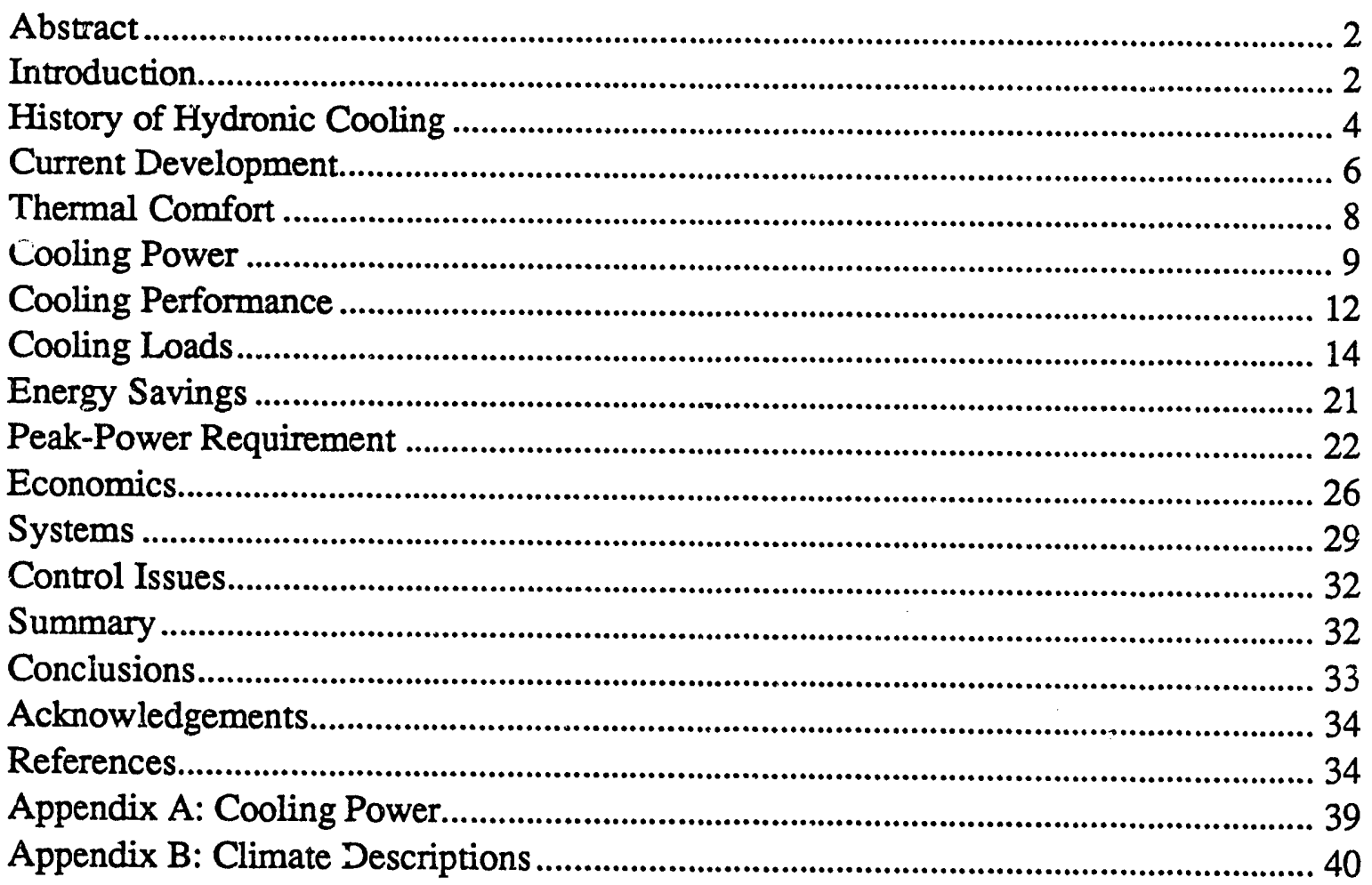




\title{
Hydronic Radiant Cooling
}

\section{Overview and Preliminary Performance Assessment}

\begin{abstract}
A significant amount of electrical energy used to cool $n$ on-residential buildings is drawn by the fans used to transport the cool air through the thermal distribution system. Hydronic systems reduce the amount of air transported through the building by separating ventilation and thermal conditioning. Due to the physical propenties of water, hydronic distribution systems can transport a given amount of thermal energy using less than 5\% of the otherwise necessary fan energy. This savings alone significantly reduces the energy consumption and especially the peak power requirement. This survey clearly shows advantages for radiant cooling in combination with hydronic thermal distribution systems in comparison with the All-Air Systems commonly used in California.

The report describes a literature survey on the system's development, thermal comfort issues, and cooling performance. The cooling power potential and the cooling power requirement are investigated for several California climates. Peak-power requirement is compared for hydronic radiant cooling and conventional All-Air-Systems.
\end{abstract}

\section{Introduction}

Cooling non-residential buildings in California contributes significantly to the electrical power consumption and the peak power demand. Part of the electrical energy used to cool buildings is drawn by fans transporting cool air through the ducts. This electricity is heating the conditioned air, and therefore, is part of the internal thermal cooling peak load. Usibelli et al. [1] found that the typical thermal cooling peak load for office buildings in California can be divided as follows: $31 \%$ for lighting, $13 \%$ for people, $14 \%$ for air transport, and $6 \%$ for equipment. External loads account for only $36 \%$ of the thermal cooling peak load.

DOE-2 simulations for different California climates using the California Energy Commission (CEC) base case office building show that, at peak load, only about $10 \%$ to $20 \%$ of the supply air is outside air [2]. Only this fraction of the supply air is necessary to properly ventilate the buildings to maintain a high level of indoor air quality. For conventional HVAC systems the difference in volume between supply air and outside air is made up by recirculated air. The recirculated air is necessary to keep the temperature difference between supply air and room air in the comfort range. The additional amount of supply air, however, often causes draft ${ }^{*}$ ) as well as indoor air quality problems by equally distributing pollutants throughout the building.

*) Draft: Air Movemeat in an occupied enclosure causing discomfort 


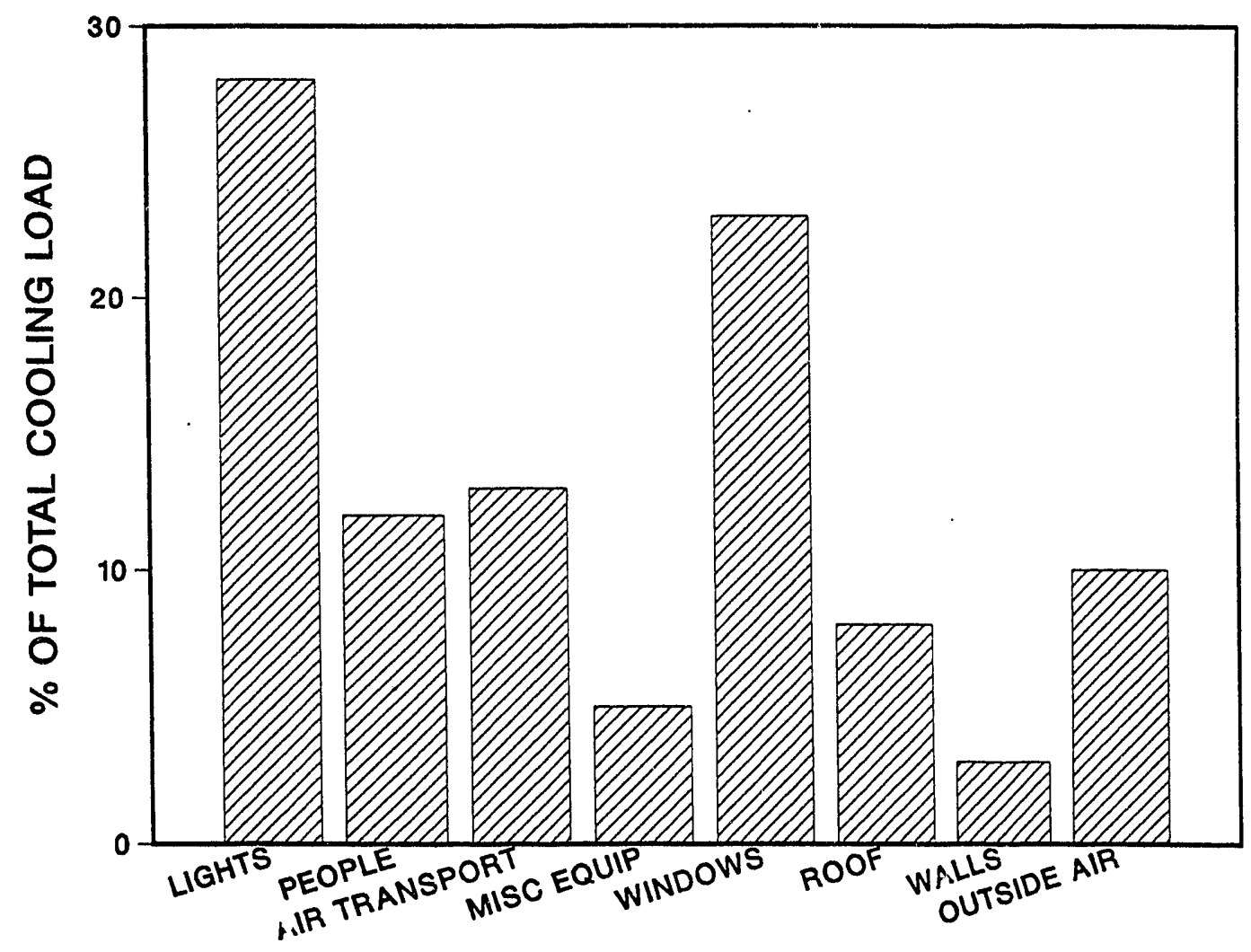

Figure 1: Cooling Load Components, Typical Office Building, Los Angeles [1]

HVAC systems are designed to maintain indoor air quality and provide thermal space conditioning. Traditionally, HVAC systems are designed as All-Air Systems, which means, that air is used to perform both tasks. All-Air Systems have been lesigned as central/decentralized systems, single/dual-path systems, constant/variable volume systems, and low/high velocity systems.

Air-and-Water Systems separate the tasks of ventilation and thermal space conditioning by using the primary air distribution to fulfill the ventilation requirements and the secondary water distribution system to thermally condition the space. These systems reduce the amount of air transported through buildings significantly, as the ventilation is provided by outside air systems without the recirculating air fraction. The cooling is provided mainly by radiation using water as the transport medium. Due to the physical properties of water, hydronic radiant cooling systems can remove a given amount of thermal energy using less than 5\% of the otherwise necessary fan energy. The separation of tasks not only improves comfort conditions, but also increases indoor air quality and improves the control and zoning of the system. Hydronic cooling systems combine controlled temperature of room surfaces with central air handling systems [3]. 
Cooling of buildings can be applied using convection only or a combination of radiation and convection. The latter uses cool surfaces in the conditioned space to cool the air and the space enclosures. Although, only approximately $60 \%$ of the heat transfer is due to radiation, these systems are often called "radiative" cooling systems. This term, however, conflicts with another cooling system where the cool sky is used to either cool outer building surfaces or radiative panels. Most literature found refers to radiative cooling or radiant cooling panels when describing hydronic radiant cooling systems. In order to avoid confusion, in the following survey we refer to hydronic cooling, reflecting the thermal distribution system used for radiant cooling systems.

Due to the large surfaces available for heat exchange in hydronic radiant cooling systems (usually almost the whole ceiling), the coolant temperature is slightly lower than the room temperature. This small temperature difference allows the use of either heat pumps with very high COP-values or indirect evaporative cooling to further reduce the electric power requirements. At the same time, hydronic radiant cooling systems reduce problems caused by duct leakage as the ventilation air is significantly reduced and only conditioned to meet room temperature rather than cooling supply air temperature conditions. Furthermore, space needs for ventilation systems and their duct work are reduced to about $20 \%$ of their original space requirements. Besides the reduction of space requirements for the shafts that house the vertical air distribution system, floor-to-fioor height can be reduced, which offsets the initial cost of the additional system. An integration between water distribution lines for hydronic radiant cooling systems and the sprinkler system might further reduce the initial cost.

The thermal storage capacity of the coolant further helps to shift the peak to later hours. Because of the hydronic energy transport, this cooling system has a potential to interact together with thermal energy storage systems (TES) and looped heat pump systems.

This report intends to give an overview over hydronic radiant cooling. It describes a literature survey on the system's development, thermal comfort issues, and cooling performance. The cooling power potential and the cooling power requirement are investigated for several California climates. Peak-power requirement is compared for hydronic radiant cooling and conventional All-Air-Systems.

\section{History of Hydronic Cooling}

Hydronic cooling was in use long before All-Air Systems were invented. Hauptmann from the University of Heidelberg recently discovered the ruins of a village in Turkey which dates back to more than 7000 B.C. [4]. Houses in this village with the kurdish name Nevala Cori utilized hydronic radiant cooling by re-routing water supplied by the Kantara Creek through channels imbedded into the buildings' slab to cool the stone floors.

The use of hydronic radiant cooling in more modern buildings had been investigated more than five decades ago. The earliest technical papers found in our literature survey date back to $1938[5,6]$. At this time the idea of hydronic radiant systems was not developed further. In 1951, Bilden [7] reports about the advantages of hydronic radiant 
heating and cooling and describes demonstration projects. At this time, the cooling effect still was more of a by-product of hydronic panel heating systems rather than the target itself. However, Bilden refers to hydronic radiant cooling systems installed in an office building in Paris, a department store in Zuerich, the Museum for Modern Art in Paris, the Hotel Excelsior in Rome, the Banque de Rome and the Palais das Journaux 9both in Milan). The combination of hydronic radiant cooling and ventilation is mentioned in the paper.

In 1957, Ronge and Lofstedt [8] investigated the physiological effects of hydronic radiant cooling, especially the draft sensation of cold ceilings and their compensation with higher air temperatures. This lead to a comfort chart which shows the interrelation between ceiling surface temperature and the air temperature. Baker [9] describes the advantages of hydronic heating and cooling, based on the heat exchange of the human body with the environment and remarked, that the heat transfer due to radiation has not been given adequate consideration. Baker lists a comfortable, healthful and more invigorating environment, more uniform air temperatures, cleaner surfaces, neater appearance, and improved efficiency, as advantages of panel systems. Condensation might be a problem if an auxiliary dehumidifying coil is not used to control the rooms dew point temperature. Although, cost of operating a cooling panel will be less than for a conventional convection system, the degree of comfort seems to be more important to Baker.

Boyar [10] in his contribution to an ASHRAE symposium in the early sixties shows that radiant panel systems have dynamic behaviour similar to All-Air Systems. At this time, panel systems must have been widely used (probably for heating purposes).

In 1973, Obrecht, Salinger and LaVanture [11] reported that radiant panel ceilings were increasingly being applied as terminal heating and cooling devices in various types of buildings. Radiant cooling panels reduce the quantity of conditioned air supply to the space. Part of the sensible cooling required might still be provided by the ventilation system which is required to supply the air necessary for hygienic reasons.

The authors suggest selecting slightly higher summer design temperatures and somewhat lower design relative humidity than for conventional All-Air Systems in order to benefit from the lower mean radiant temperature, which allows higher ambient air temperatures and still provides the same degree of comfort. As heat removal from the space is a function of the temperature difference between the water and the room (air and surface temperatures), the design relative humidity and dew point should be selected as low as economically feasible. The supply water temperature is usually $1^{\circ} \mathrm{C}$ higher than the design dew point and a temperature rise of $4^{\circ} \mathrm{C}$ throughout the system is used. This usually leads to a temperature difference of approximately $10^{\circ} \mathrm{C}$ between the design dry bulb temperature and the mean water temperature.

Although, many authors have reported significant advantages of hydronic radiant cooling over All-Air Systems, even the two energy crises did not seem to have an effect on the development and the use of hydronic radiant cooling systems. Increasing energy prices did not change the market share of hydronic radiant cooling systems. 


\section{Current Development}

During the last decade building inhabitants developed a critical attitude towards air conditioning systems. Terms like complaint buildings and sick buildings were born. Several publications dealing with occupant satisfaction in air-conditioned and naturally ventilated buildings came to the conclusion that the number of unsatisfied in air-conditioned buildings is significantly higher than in natural ventilated buildings [12-14]. Esdorn et al. [15] state, that there are still air-conditioning systems that do not produce the required standard of comfort. "The existence of air-conditioning systems is actually only noticed when it is not functioning properly."

Draft is a serious problem in many air-conditioned buildings. As air from HVAC systerns is normally turbulent in the occupied zone, even small air velocities (less than $0.1 \mathrm{~m} / \mathrm{s}$ !) might cause an unwanted local cooling of the human body [16]. In order to be able to extract cooling loads from a building, the cooled air either exceeds the outdoor air needed for ventilation (recirculating air system) or temperature differences between the supply air and the room air have to be so large that its supply might cause problems to evenly distribute in the occupied zone (cold air distribution systems).

Whereas the use of recirculation air might cause draft and/or indoor air quality problems due to the distribution of the polluted return air, cold air distribution systems can cause very cold local drafts if imperfect mixing between supply air and room air occurs at the air outlet. Both cases will cause comfort problems. Because of comfort problems and the excessive use of transport energy for All-Air-Systems new ventilation strategies were developed [17], such as displacement ventilation.

The idea of displacement ventilation is to overcome the problems of mixing ventilation systems. Contaminants are displaced from the breathing zone and clean air is directly supplied with air flow of low turbulent intensity to the breathing zone [18]. An upward displacing direction is most efficient for cooling purposes. This strategy will always result in increased air temperature with height. The heat sources in the room are the driving forces of the vertical air transport by creating convective air currents (plumes) $)^{\dagger}$. This air flow pattern results in greatly improved ventilation efficiency (for definition of ventilation efficiency, see Sutcliff [19]). Ventilation systems with high ventilation efficiencies use solely outdoor air and, therefore, can only extract limited amounts of cooling loads $[20,21]$. Upward displacement ventilation shows a characteristic temperature profile caused by the convective currents due to the heat sources. As supply air is entering the room at floor level, the temperature gradient forms a barrier for low energy currents to reach high altitudes in the room. Due to comfort requirements, the temperature gradient between feet and head should not exceed $3^{\circ} \mathrm{C}$, which further limits the cooling capacity of these ventilation systems [18].

In order to use these energy efficient ventilation systems, another cooling source had to be found. The logical choice was a coupling of efficient ventilation systems with hydronic radiant cooling systems, separating the tasks of ventilating and cooling the

† Displacement ventilation should not be mistaken for "plug flow" or "piston flow"; plume flow ventilation might be a better term 


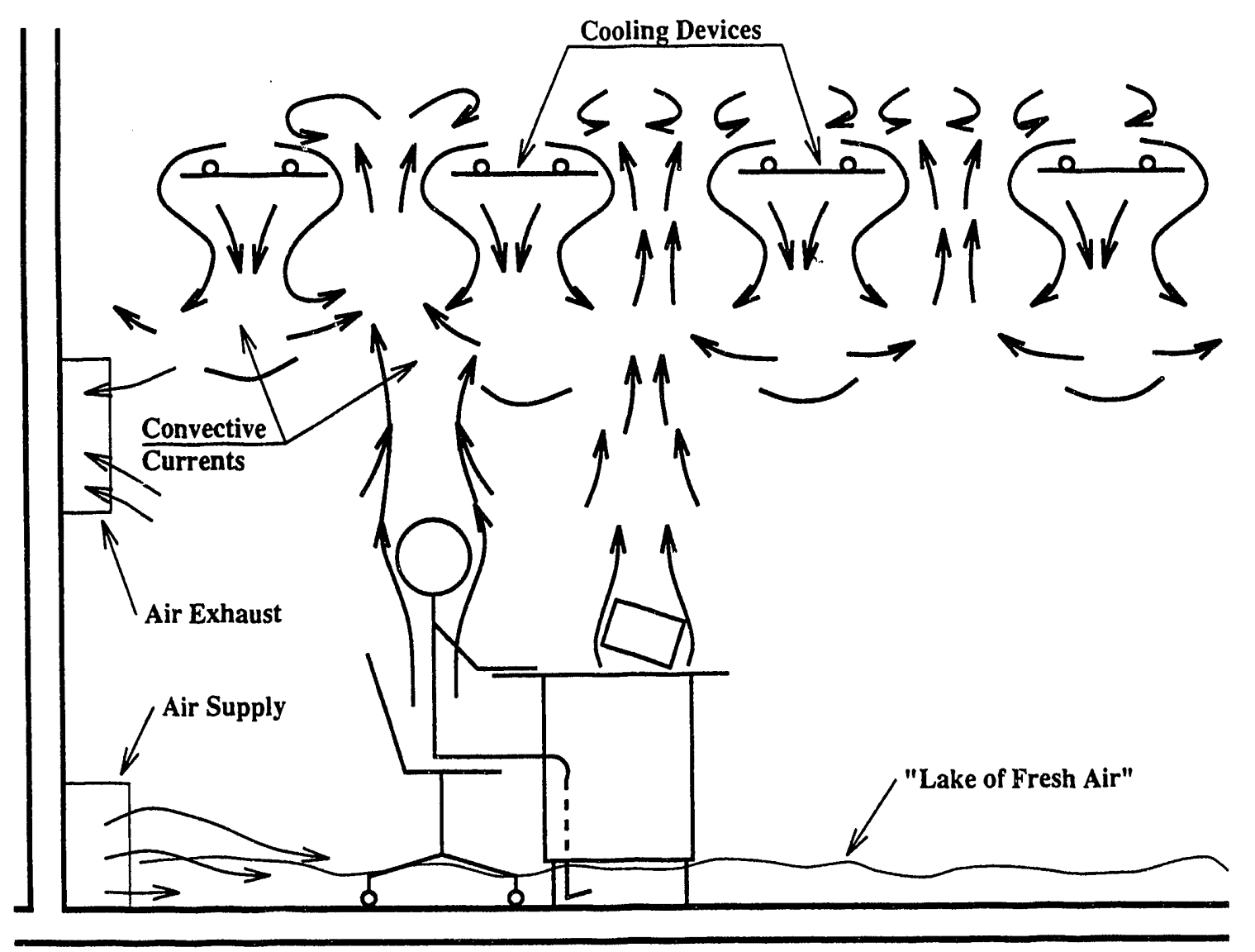

Figure 2: Air Flow Patterns in a Room with a Cooled Ceiling [18]

building. The theoretical air flow pattern in a room with a cooled ceiling is shown in Figure 2.

\section{Thermal Comfort}

The human body is a generator of heat. In order to maintain normal functions the balance between heat gain and heat loss must be maintained. Heat can be lost by different ways: radiation to surrounding surfaces, convection to the ambient air, evaporation, respiration and excretion [22-25]. The publications came to the same main conclusion: the heat loss due to radiation has the highest portion, followed by convection and conduction. Respiration and excretion have less influence on the heat loss of a human body.

Baker gives the following example explaining the impact of radiation: "A person sitting out of doors under a clear sky on a summer evening may be chilly although the air temperature is in the high $70^{\prime} \mathrm{s}\left({ }^{\circ} \mathrm{F}\right)$. Were he indoors at this same temperature, he probably would feel uncomfortably warm. The appreciable heat loss by radiation to the clear sky 
explains the different sensations of comfort between outdoors ardid indoors." This example suggests, that the surface temperatures surrounding an occupant within an enclosure has to be considered. Heat loss by radiation and convection may be considered collectively, only if all surface temperatures are close to the ambient air temperature.

Losing the heat by convection only would require a high air velocity close to the human's skin and would finally lead to draft and, therefore, to uncomfortable conditions. The possibilities of increasing the heat loss by respiration or excretion are practically noexistent. This shows that not only the air temperature is important for comfortable conditions, but also the temperatures of the surrounding surfaces which cause heat loss due to radiation.

Because of the irregular surface of the body, the heat loss depends not only on the temperature differences, but also on clothing and activity [26]. ASHRAE Standard 55 [27] specifies the combination of the environmental parameters of air temperature, thermal radiation, humidity, air movement, personal parameters of clothing and activity.

Clothing, through its insulation properties, is an important modifier of body heat loss and comfort. Clothing insulation can be described in terms of its clo-Value. For instance, a heavy two-piece business suit with accessories has an insulation value of about 1 clo while a pair of shorts is about 0.05 clo. The insulation of the clothing can be estimated by summing the clo values of the individual items worn and multiplying the sum by a reduction factor [27]. The operative temperature is approximately the average of the air temperature (dry buih temperature at air speeds of $0.4 \mathrm{~m} / \mathrm{s}$ or less) and mean radiant temperature (if less than $50^{\circ} \mathrm{C}$ ).

The optimum operative temperature is decreased if the average activity level of the occupants is higher than sedentary. The body will then increase the rate of energy production. The energy production is expressed in met units (metabolic rate). One met is defined as $58.2 \mathrm{~W} / \mathrm{m}^{2}$, which is equal to the energy produced per unit surface area of a seated person at rest. The surface area of an average man is about $1.8 \mathrm{~m}^{2}$ [27].

The operative temperature for different activities depends on both: activity level and clothing insulation.

According to Table 1, the heat loss due to radiation has the most influence on the human's heat loss and thus on his state of comfort. The mean radiant temperature, which depends on the temperatures of the surrounding surfaces, is responsible for heat loss by radiation. The mean radiant temperature is easy to define but quite complicated to calculate or measure in practice. The first experiments of thermal and comfort sensations of sedentary persons to radiation were conducted by McNall, Biddison [28], and Schlegel, McNall [29]. The most extensive experimental investigations have been made by Fanger [26] in order to show that mean skin temperature and sweat secretion are closely connected with the sensation of thermal comfort. 128 college-age persons (64 males and 64 females) and 128 elderly persons (64 males and 64 females) were used for his experiments. Fanger defined mean radiant temperature as follows: "The mean radiant temperature in relation to a person in a given body posture and clothing placed at a given point in a room, is defined as that uniform temperature of black surroundings which will give the 
same radiant heat loss from the person as the actual case under study." [26]

\begin{tabular}{|l|c|}
\hline Table 1: Heat Loss of a Human Body [22] \\
\hline Radiation & $40-50 \%$ \\
Convection & $20-26 \%$ \\
Evaporation & $18-20 \%$ \\
Respiration & $6-10 \%$ \\
Excretion & $-6 \%$ \\
\hline
\end{tabular}

Due to the non-uniform distances and angles of persons related to the walls, floor and ceiling, each part of the room must be considered separately. If a given surface is found not to be isothermal, it has to be divided into smaller surfaces, which are isothermal by themselves. Each surface can be assumed to be grey. The radiation emitted and reflected from any surface is diffusely distributed, which is a good approximation for all normal non-metallic surfaces [26].

The enclosure surfaces often found in a normal room are rectangular in form and, therefore, it is the angle factor between a person and a vertical or horizontal plane. The body posture also plays an important part. The mean radiant temperature in relation to a standing person need not be the same as in relation to a seated one [26]. Likewise, the person's location and orientation within the room must also be known, because the mean radiant temperature uften varies from point to point.

Air movement plays a special role among the comfort parameters. According to Esdorn et al. [15], air movement is the biggest single cause for complaints (draft). Besides the mean velocity, the fluctuation of the velocity has an important influence on the convective heat transfer of the human body. Mayer [30] relates comfort directly to the convective heat transfer coefficient rather than to the mean air velocity. According to Mayer [31] at an air temperature of $22^{\circ} \mathrm{C}$ draft is felt if the convective heat transfer coefficient is above $12 \mathrm{~W} / \mathrm{m}^{2} \mathrm{~K}$. This translates to mean air velocities for laminar flows of $1.35 \mathrm{~m} / \mathrm{s}$; for transition flow of $0.15 \mathrm{~m} / \mathrm{s}$, and for turbulent flow of $0.10 \mathrm{~m} / \mathrm{s}$. Lover air temperatures significantly reduce the acceptable air velocities.

\section{Cooling Power}

The cooling power of hydronic radiant cooling systems is limited by several parameters. First, the surface temperatures of the cooling elements should not be lower than the dew point of the air in the cooled zone. The dew point can be manipulated by reducing the air's humidity content. A more serious concern is the comfort effect of the asymmetrical distribution of the radiant temperature. Kollmar [32] shows that for offices, ceiling temperatures of approximately $15^{\circ} \mathrm{C}$ are the lower limit. 
The heat transfer between the room and the cold ceiling is based on radiation and convection. Whereas the heat transfer of radiation is relatively easy to calculate, the convective heat transfer is a function of the air velocity at the ceiling level. This velocity is dependent on the room geometry, the location and power of the heat sources, and the location of the air intake and exhaust.

Trogisch [33] compares heat transfer coefficients for cooled ceilings found in the literature with the description of convective heat transfer from a cold flat surface (downwards) as published in textbooks. Investigations dealing with cooled ceilings show heat transfer coefficients of 9 to $12 \mathrm{~W} / \mathrm{m}^{2} \mathrm{~K}$. With a heat transfer coefficient for radiation of about 5.5 $\mathrm{W} / \mathrm{m}^{2} \mathrm{~K}$ (for $=10 \mathrm{~K}$ ), the convective heat transfer coefficient must be in the magnitude of 3.5 to $6.5 \mathrm{~W} / \mathrm{m}^{2} \mathrm{~K}$. These values, however, can only be reached if forced convection takes place (here forced means that other phenomena than the cooling at the ceiling are responsible for driving the air flow).

Radiant cooling elements extract heat from a room by cooling the air (convection) and by cooling the surfaces of the room's envelope. The two effects can be described by an empirical equation which is based on the assumption that the mean surface temperature of the room differs only slightly from the air temperature [34]. With this assumption, we can express the specific cooling power (per square meter) of a cooled ceiling by the following equation:

$$
q_{\text {tot }}=8.92\left[t_{\text {air }}-t_{\text {surface }}\right]^{1.1}
$$

$\mathbf{q}_{\text {tot }}$

sum of convective and radiant heat transfer $\left[\mathrm{W} / \mathrm{m}^{2}\right]$

With the information about the heat transfer coefficient $\left(\alpha_{\text {tot }}=11-12 \mathrm{~W} / \mathrm{m}^{2} \mathrm{~K}\right)$ and the lower limit of the ceiling surface temperature $\left(t_{s}=15^{\circ} \mathrm{C}\right)$, one can reach a specific cooling power of approximately 110 to $120 \mathrm{~W} / \mathrm{m}^{2}$ through hydronic radiative cooling. In zones with more than one exterior wall, slightly higher specific cooling powers can be achieved due to higher radiative temperature differences. If forced convection is provided by the ventilation system, the cooling performance of the panel system can be increased.

Although, attempts have been made to numerically determine the cooling power of hydronic systems, there seems to be no standard available for testing cooling panels. ASHRAE's technical committee TC 6.5 Radiant Space Heating and Cooling is sponsoring a committee on Methods of Testing/Rating Hydronic Radiant Ceiling Panels (SPC 138P). The purpose of SPC 138P is to establish a method of testing for rating the thermal performance of hydronic radiant cooling panels used for heating and/or cooling of indoor space [35]. A test facility and a method of testing was developed at the Department of Veterans Affairs [36]. The paper describes the testing procedure for thermal performance and pressure drop measurements, the test facility as well as the accuracy of the instrumentation to be used. 
Whereas testing procedures and future standards will rate the performance of the panel, the efficiency of the system is difficult to determine. A high panel efficiency could be produced by providing high air velocities at the panel surface through a shortcut between the supply and the exhaust of the ventilation system. Although the panel would show high performance, part of the convective heat transfer could be diminished by exhausting cooled air rather than supplying the air to the occupied zone.

In order to avoid condensation, the temperature of the surface of the cooling panel has to be above the dew point. The temperature difference between the room air and the dew point temperature is theoretically the upper limit for cooling power. In practice, however, the effective cooling temperature difference is reduced by a safety-margin of approximately $2 \mathrm{~K}$.

To determine the effective temperature differences which can be utilized for radiant cooling some California and non-California climates were analyzed [37] The description of the climates as published by the National Oceanic and Atmospheric Administration [38] is shown in Appendix B.

Table 2 shows some extreme values for air properties for four California and one nonCalifornia climate. The humidity ratio and the outdoor air temperatures together with the effective temperature difference available for cooling are listed for the hottest hour and the most humid hour.

\begin{tabular}{|c|c|c|c|c|c|}
\hline Location & $\left.\frac{x}{\left[g / g_{d r y} \text { air }\right.}\right]$ & $\stackrel{t}{t}\left[{ }^{\circ} \mathrm{C}\right]$ & $\begin{array}{c}\tau \\
{\left[{ }^{\circ} \mathrm{C}\right]}\end{array}$ & $\begin{array}{l}\mathrm{t}_{\mathrm{MWT}} \\
\left.{ }^{\circ} \mathrm{C}\right]\end{array}$ & $\begin{array}{c}\Delta \mathrm{t}_{\text {eff }} \\
{[\mathrm{K}]}\end{array}$ \\
\hline $\begin{array}{l}\text { Arcata } \\
\text { Long Beach } \\
\text { Red Bluff } \\
\text { San Diego }\end{array}$ & $\begin{array}{r}8 \\
4 \\
3 \\
12\end{array}$ & $\begin{array}{l}26 \\
37 \\
48 \\
39\end{array}$ & $\begin{array}{l}10.5 \\
1.5 \\
-3 \\
16.5\end{array}$ & $\begin{array}{c}12.5 \\
3.5 \\
-1 \\
18.5\end{array}$ & $\begin{array}{c}13.5 \\
22.5 \\
27 \\
7.5\end{array}$ \\
\hline Lake Charles & 17 & 35 & 22.0 & 24.0 & 2.0 \\
\hline
\end{tabular}

$$
\begin{array}{ll}
\mathbf{x} & =\text { humidity ratio (outside conditions) } \\
\mathbf{t} & =\text { dry bulb temperature (outside conditions) } \\
\tau & =\text { dew point temperature (outside conditions) } \\
t_{\mathrm{MWT}} & =\text { mean water temperature }
\end{array}
$$

with: $\quad t_{M W T}=\tau+2 K$

and : $\quad \Delta t_{\text {eff }}=t_{\text {Room }}-t_{M W T} ;$ with $t_{\text {Room }}=26^{\circ} \mathrm{C}$

We see, that in the case of the most humid hour, the effective temperature difference proves to be relatively small for all chosen climates. Measures have to be taken to reduce the dew point of the room air to obtain reasonable effective temperature differences. 


\begin{tabular}{|l|c|c|c|c|c|}
\hline \multicolumn{6}{|c|}{ Table 2b): Air Properties for the most Humid Hour for Several Locations } \\
\hline Location & $\begin{array}{c}\mathrm{x} \\
{\left[\mathrm{g} / \mathrm{kg}_{\text {dry air }}\right]}\end{array}$ & $\begin{array}{c}\mathrm{t} \\
{\left[{ }^{\circ} \mathrm{C}\right]}\end{array}$ & $\begin{array}{c}\tau \\
{\left[{ }^{\circ} \mathrm{C}\right]}\end{array}$ & $\begin{array}{c}\mathrm{t}_{\mathrm{MWT}} \\
{\left[{ }^{\circ} \mathrm{C}\right]}\end{array}$ & $\begin{array}{c}\Delta \mathrm{t}_{\mathrm{eff}} \\
{[\mathrm{K}]}\end{array}$ \\
\hline Arcata & 12 & 18 & 16.6 & 18.6 & 7.4 \\
Long Beach & 16 & 32 & 21.2 & 23.2 & 2.8 \\
Red Bluff & 14 & 34 & 19 & 21 & 5 \\
San Diego & 16 & 28 & 21.2 & 23.2 & 2.8 \\
\hline Lake Charles & 18 & 34 & 23 & 25 & 1 \\
\hline
\end{tabular}

\section{Cooling Performance}

Although, several papers describing the cooling power of hydronic radiant systems have been found in the literature, few articles deal with the performance of these systems. Kuelpmann and Escom [39] report on their experimental investigation in a temperature controlled test cell (see Figure 3). The ventilation air was supplied at floor level and exhausted approximately $0.2 \mathrm{~m}$ below the ceiling level. Internal loads were simulated by electrically heated mannequins (dummies) standing next to a computer display and by fluorescent lights. External loads were introduced by heating either one of the long side walls or the floor. For displacement ventilation and no cooling with supply air, room air temperatures did not differ very much over height (see Figure 4). The extraction of 100 $\mathrm{W} / \mathrm{m}^{2}$ internal load by hydronic radiant cooling caused temperature differences of approximately $2 \mathrm{~K}$ between supply and exhaust grille. With increasing temperature difference between the room air and the supply air, the profile became more pronounced. Especially in the lower part of the room, these temperature differences get close to or exceed the comfort limits.

In all examined cases the differences between the room air temperature and the surface temperatures of the "internal walls" were relatively small $( \pm 0.4 \mathrm{~K})$. Due to the radiation exchange with the cool ceiling, the floor surface temperature is usually below the wall surface temperatures.

Asymmetric or non-uniform thermal radiation may be caused in winter by cold windows, uninsulated walls or heated ceilings. In surnmer, cool ceiling panels also produce asymmetric thermal radiation. Radiant asymmetry due to a cool ceiling causes less discomfort than a warm ceiling. Based on Fanger's assumption to accept 5\% dissatisfied, a radiant temperature asymmetry of $10 \mathrm{~K}$ is allowable at a cool wall and $14 \mathrm{~K}$ under a cool ceiling (see Figure 5) [40]. Measurements of radiant temperature asymmetry at $100 \mathrm{~W} / \mathrm{m}^{2} \mathrm{cool}-$ ing power resulted in $5.3 \mathrm{~K}$ in $1.1 \mathrm{~m}$ above the floor level in the middle of the room. This corresponds to approximately $1 \%$ ciissatisfied.

Air flow velocities were measured in $1 \mathrm{~m}$ distance to the supply air grille in $0.1 \mathrm{~m}$ height above ground. At an air exchange rate of 3.2 ach and a supply air temperature of $19^{\circ} \mathrm{C} \mathrm{a}$ velocity of $0.12 \mathrm{~m} / \mathrm{s}$ and a turbulence intensity of $20 \%$ was measured. The air temperature was $20^{\circ} \mathrm{C}$. 

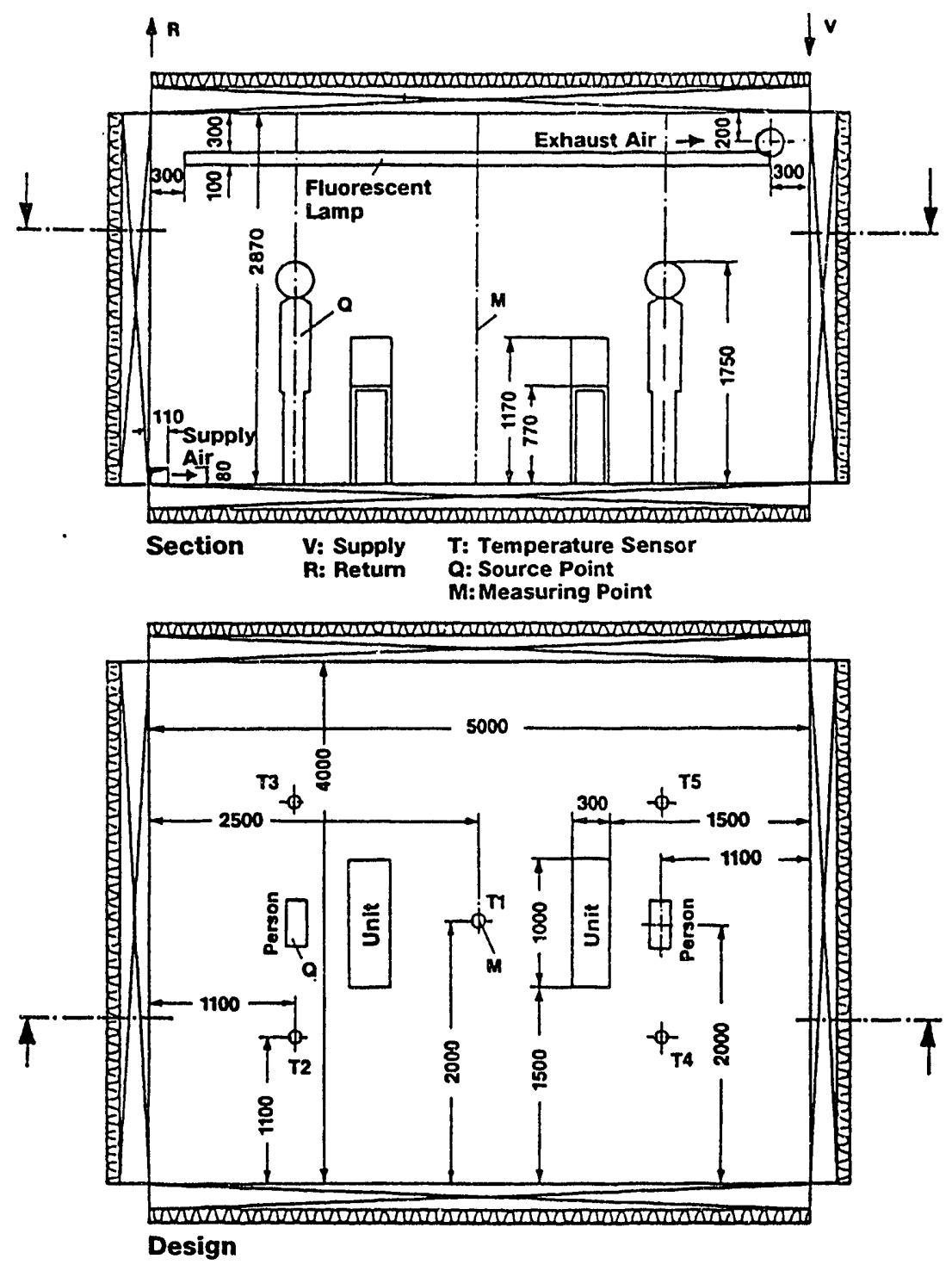

Figure 3: Test Chamber used to Test Cooling Performance of Hydronic Cooling [39]

The performance of hydronic radiant cooling was tested in two parliamentarian offices in Bonn, F.R.G. [41]. Dry-bulb temperatures and relative humidity were measured in the ambient air, the supply air and the room air. Furthermore, temperatures were measured in the supply and return pipe of the hydronic system and at three points at the ceiling surface. At ambient temperatures of $30^{\circ} \mathrm{C}$ air velocities below $0.10 \mathrm{~m} / \mathrm{s}$ were measured in the occupied zone. Below the ceiling surface velocities between 0.10 and $0.15 \mathrm{~m} / \mathrm{s}$ were detected. 


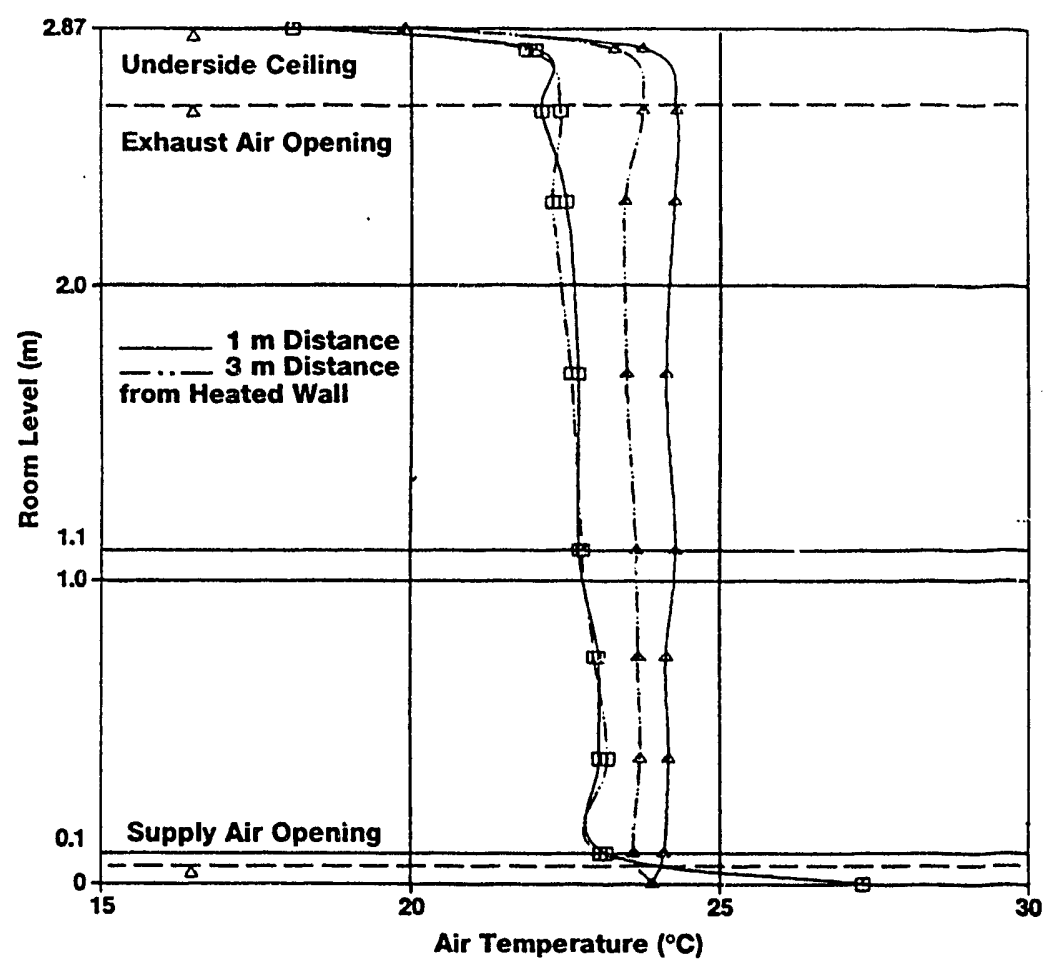

\begin{tabular}{|c|c|c|c|c|c|c|}
\hline Symbol & $\begin{array}{l}\text { Cooling } \\
\text { Type }\end{array}$ & $\begin{array}{c}\text { L Load } \\
\text { Value } \\
\text { W/m²) }\end{array}$ & $\begin{array}{c}\text { Room } \\
\text { Temperature } \\
t_{R}\left({ }^{\circ} \mathrm{C}\right)\end{array}$ & $\begin{array}{c}\text { Temp.-Diff. } \\
\text { Walls-Air } \\
\text { (K) }\end{array}$ & $\begin{array}{c}\text { Perform } \\
\text { Ceiling }(-) \\
\omega_{b}\end{array}$ & $\begin{array}{c}\text { ce Part } \\
\text { Air }(-) \\
\omega_{L}\end{array}$ \\
\hline $\begin{array}{l}{[]} \\
\Delta\end{array}$ & $\begin{array}{l}W \\
\mathbf{F b}\end{array}$ & $\begin{array}{l}39.7 \\
40.5\end{array}$ & $\begin{array}{l}24.0 \\
23.0\end{array}$ & $\begin{array}{l}0.2 \\
0.1\end{array}$ & $\begin{array}{l}1.00 \\
1.00\end{array}$ & $\begin{array}{l}0.00 \\
0.00\end{array}$ \\
\hline
\end{tabular}

W: Wall Fb: Floor

Figure 4: Air Temperature Profile over the Room Height as a Function of External Loads [39]

The simulation of the system performance of a cooled ceiling for a continental European climate shows only few hours per year where the set point temperature of the room cannot be met by the system [42]. The office building is made of reinforced concrete with a window area of $33 \%$ of the exterior wall. The south-west oriented zone experiences a maximum of $30 \mathrm{~W} / \mathrm{m}^{2}$ external loads and $57 \mathrm{~W} / \mathrm{m}^{2}$ internal loads. Occupancy is 16 $\mathrm{m}^{2} /$ person. The air exchange rate due to ventilation $(0.8 \mathrm{ach})$ was sufficient to avoid condensation problems.

\section{Cooling Loads}

In order to determine the cooling loads one has to expect in California climates, the Base-Case building used by the California Energy Commission (CEC) was simulated using weather data for the four California climates (Arcata, Long Beach, Red Bluff, San Diego) and for Lake Charles. The building used for the simulation runs is the low-rise 


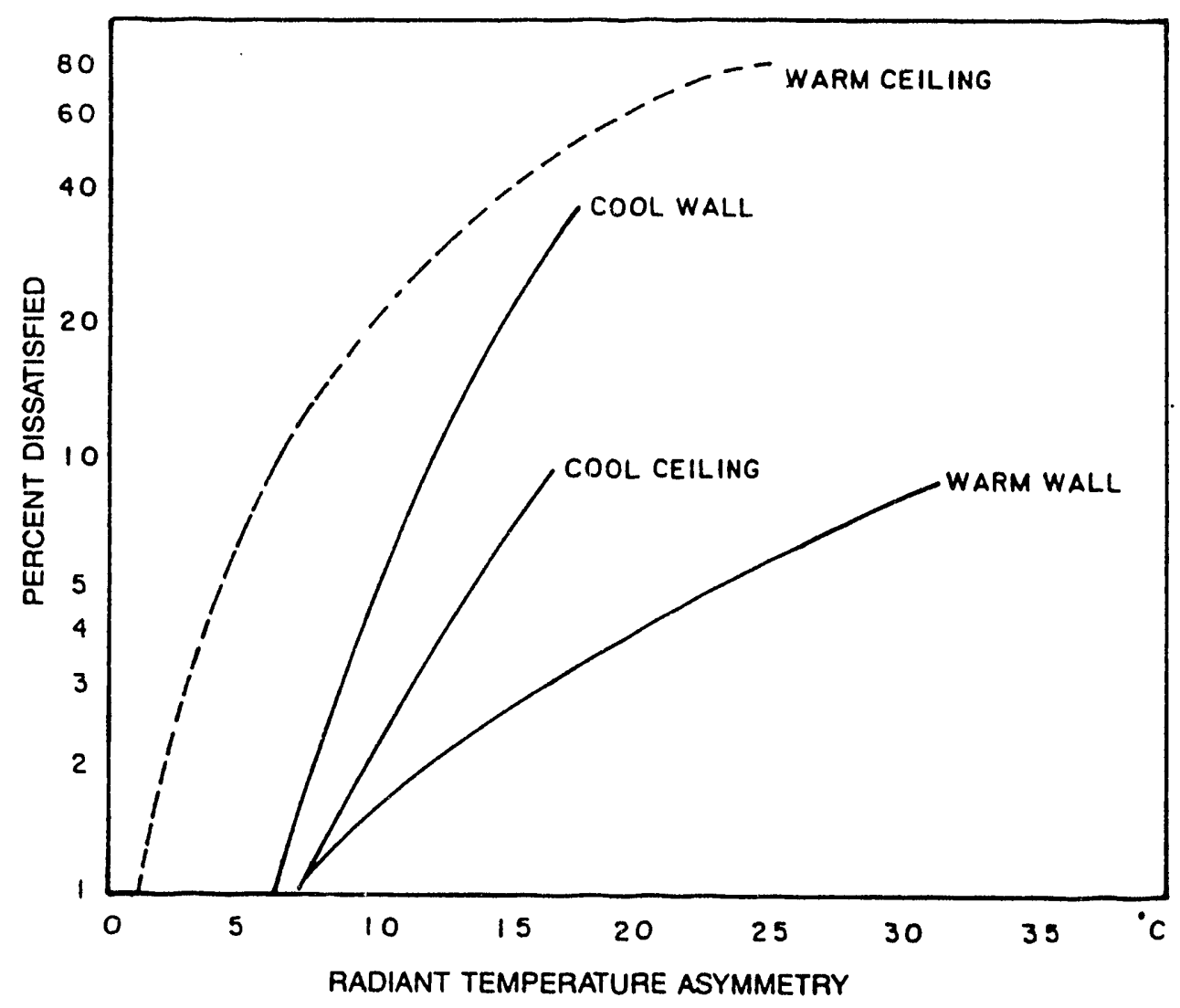

Figure 5: Percentage of People expressing Discomfort due to Asymmetric Radiation [40]

office base-case building described in the Compliance Options Approval Manual, published by the California Energy Commission [43]. The office building was simulated using the building simulation model DOE - 2.1D [44].

The low-rise office building used for the building simulation is a two story, 1,860 square meters office building, built siab on grade (see Fig. 6). The building is divided into ten different zones. The air to condition each of the zones is supplied by package single zone systems (PSZ). Lighting is provided by recessed fluorescent luminaires, installed to 15 $\mathrm{W} / \mathrm{m}^{2}$. There is an additional load of $5 \mathrm{~W} / \mathrm{m}^{2}$ from receptacles. Wond frame exterior walls are insulated with $1.9 \mathrm{~K} \mathrm{~m}^{2} / \mathrm{W}$ (R-11) batt insulation. Walls are designed with studs ( $50 * 100 \mathrm{~mm}, 400 \mathrm{~mm}$ on center) supported by $16 \mathrm{~mm}$ exterior Plywood and $16 \mathrm{~mm}$ Gypsum Board inside. Windows consist of $6 \mathrm{~mm}$ single pane heat absorbing glass with metal frames. Glass covers $30 \%$ of the exterior wall area. The roof is insulated with 1.9 $\mathrm{K} \mathrm{m}^{2} / \mathrm{W}(\mathrm{R}-11)$ batt insulation. The concrete floor includes an $0.8 \mathrm{~K} \mathrm{~m} / \mathrm{W}(\mathrm{R}-4.5)$ insulation. 

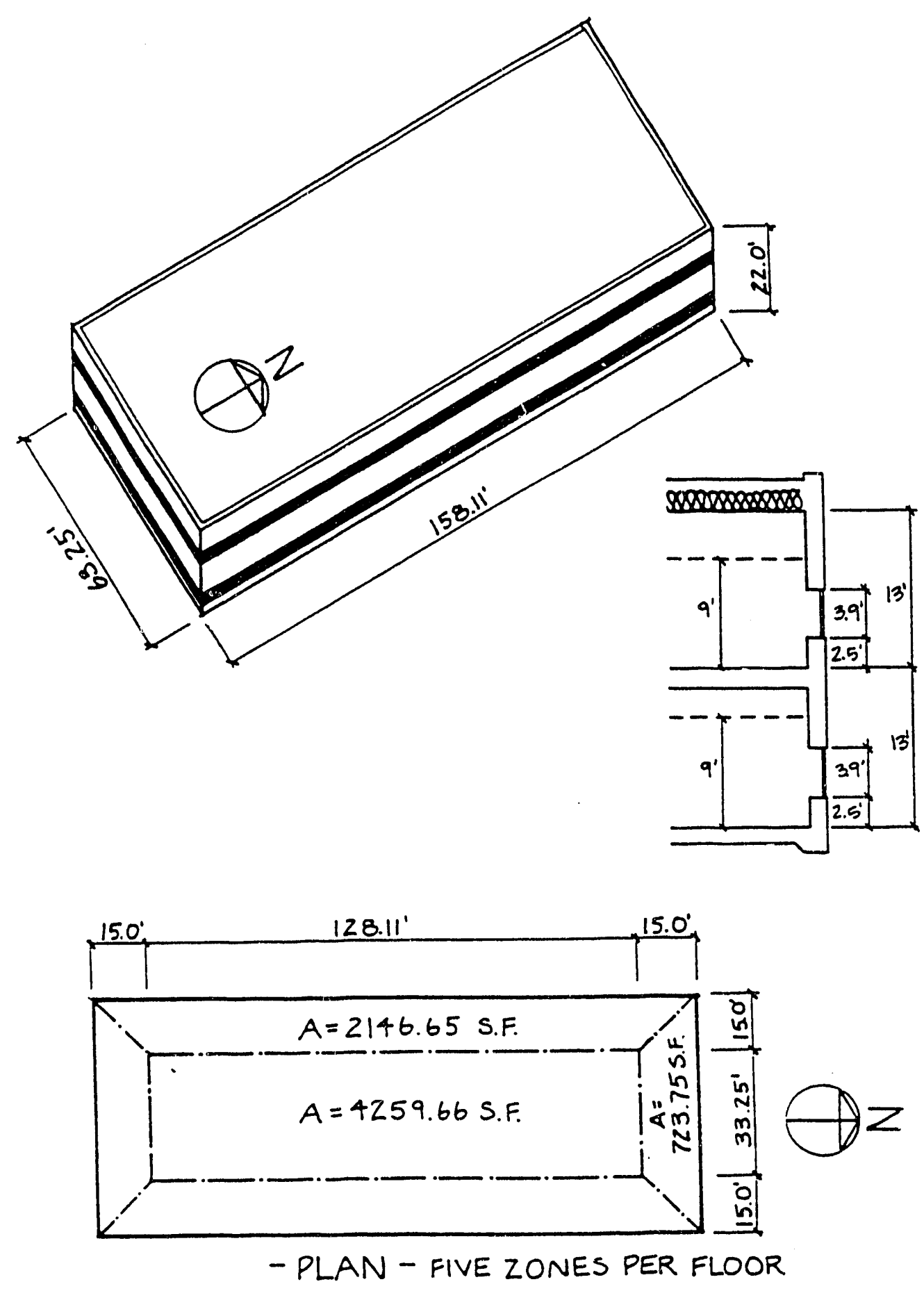

Figure 6: Low-Rise Office Building [43] 
Occupancy during working hours is 23.3 square meters per person, with 65 Watt sensible and 54 Watt latent heat per person, which translates to a humidity load of $75 \mathrm{~g} /(\mathrm{h}$ pers). The HVAC system is off between 18 p.m. and 7 a.m. from Monday through Friday and during all weekends and holidays. If the fan is off, infiltration occurs at a rate of 0.7 $\mathrm{m}^{3} /\left(\mathrm{hm}^{2}\right)$ of exterior wall area.

The cooling peak loads for the different climates show significant differences for the building location, but also for the zones of the buildings. Due to the additional heat transfer, the zones in the second storey experience higher loads than the zones downstairs. In all cases the South zones and the West zones show the highest specific loads. Table 3 shows the cooling peak loads for the locations simulated.

Table 3: Cooling Peak Loads for the different Zones of the Base-Case Building for the Day of the Building Peak Load [W/ $/ \mathrm{m}^{2}$ floor area]

\begin{tabular}{|l|r|c|r|r|r|}
\hline & Arcata & Long Beach & Red Bluff & San Diego & Lake Charles \\
\hline First Floor: & & & & & \\
North I & 32 & 58 & 90 & 70 & 62 \\
South I & 121 & 137 & 149 & 130 & 122 \\
West I & 93 & 112 & 149 & 115 & 116 \\
East I & 88 & 102 & 135 & 100 & 107 \\
Interior I & 22 & 22 & 22 & 22 & 22 \\
\hline Second Floor: & & & & & \\
North II & 47 & 72 & 112 & 84 & 83 \\
South II & 144 & 160 & 177 & 151 & 147 \\
West II & 109 & 136 & 179 & 139 & 147 \\
East II & 99 & 120 & 157 & 120 & 131 \\
Interior II & 35 & 37 & 44 & 33 & 40 \\
\hline Whole Building & 51 & 63 & 84 & 62 & 63 \\
\hline
\end{tabular}

The highest loads are associated with the location of Red Bluff. Therefore, the peak load components for this particular case are listed in Tables 4a) and 4b). Results from the simulation runs show relatively high cooling peak loads for all eight perimeter zones. Even the north-zones show peak cooling loads of $90 \mathrm{~W} / \mathrm{m}^{2}$ floor area for the first floor and $112 \mathrm{~W} / \mathrm{m}^{2}$ for the second floor. The west zone on the second floor has the highest load with $187 \mathrm{~W} / \mathrm{m}^{2}$ which has its peak on the late afternoon. Interior zones, which have the same specific interior loads as the other zones, show peak loads of about $22 \mathrm{~W} / \mathrm{m}^{2}$ for the first floor and $45 \mathrm{~W} / \mathrm{m}^{2}$ for the second floor. The difference between the two interior zones is based on the additional load the second storey zones get from the roof.

The peak loads calculated for the three perimeter zones cannot be removed by radiant cooling ceilings without special measures to avoid condensation. Furthermore, the large 
Table 4a: Peak Loads for individual Building Components for Base-Case Building, First Floor [ W/m $\mathrm{m}^{2}$ floor area], Red Bluff

\begin{tabular}{|l|c|c|c|c|c|}
\hline & North I & East I & South I & West I & Interior I \\
\hline & $7 / 14,5 \mathrm{pm}$ & $7 / 15,11 \mathrm{am}$ & $10 / 6,3 \mathrm{pm}$ & $7 / 14,6 \mathrm{pm}$ & $12 / 18,5 \mathrm{pm}$ \\
\hline Walls & 9 & 7 & 8 & 10 & 0 \\
Roof & 0 & 0 & 0 & 0 & 0 \\
Glass Conduction & 41 & 26 & 14 & 34 & 0 \\
Glass Solar & 21 & 84 & 108 & 91 & 0 \\
Underground Surfaces & -0.7 & -0.7 & -0.5 & -0.7 & 0 \\
Occupants to Space & & & & & \\
$\quad$ sensible & 2 & 2 & 2 & 1 & 3 \\
latent & 2 & 2 & 2 & 1 & 2 \\
Light to Space & 12 & 11 & 11 & 11 & 12 \\
Equipment to Space & 4 & 4 & 4 & 4 & 5 \\
\hline Total & 90.3 & 135.3 & 148.6 & 151.3 & 22 \\
\hline
\end{tabular}

Table 4b: Peak Loads for individual Building Components for Base-Case Building, Second Floor [ W/m $/ \mathrm{m}^{2}$ floor area], Red Bluff

\begin{tabular}{|l|c|c|c|c|c|}
\hline & North II & East II & South II & West II & Interior II \\
\hline & $7 / 14,5 \mathrm{pm}$ & $7 / 15,11 \mathrm{am}$ & $10 / 6,3 \mathrm{pm}$ & $7 / 15,7 \mathrm{pm}$ & $7 / 15,5 \mathrm{pm}$ \\
\hline Walls & 9 & 7 & 9 & 12 & 0 \\
Roof & 18 & 10 & 11 & 18 & 22 \\
Glass Conduction & 42 & 27 & 15 & 31 & 0 \\
Giass Solar & 23 & 94 & 122 & 102 & 0 \\
Underground Surfaces & 0 & 0 & 0 & 0 & 0 \\
Occupants to Space & 2 & 2 & 2 & 1 & 3 \\
$\quad$ sensible & 2 & 2 & 2 & 0 & 2 \\
latent & 12 & 11 & 11 & 10 & 13 \\
Light to Space & 4 & 4 & 4 & 4 & 5 \\
Equipment to Space & 112 & 157 & 176 & 181 & 45 \\
\hline Total & & & & & \\
\hline
\end{tabular}

temperature difference between the cool ceiling and the air might cause a significant down-draft in the room. 


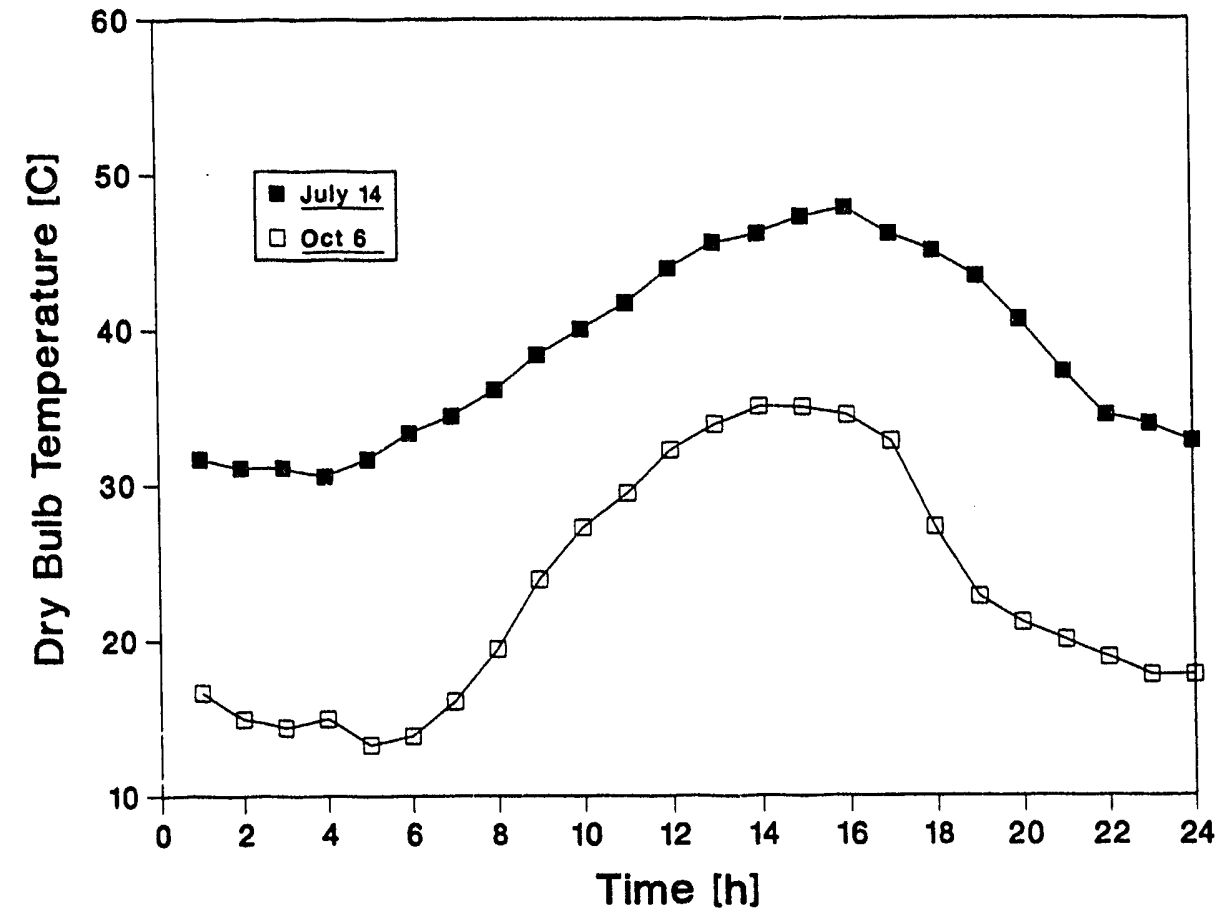

Figure 7a: Temperature Profiles for Red Bluff, July 14 and October 6

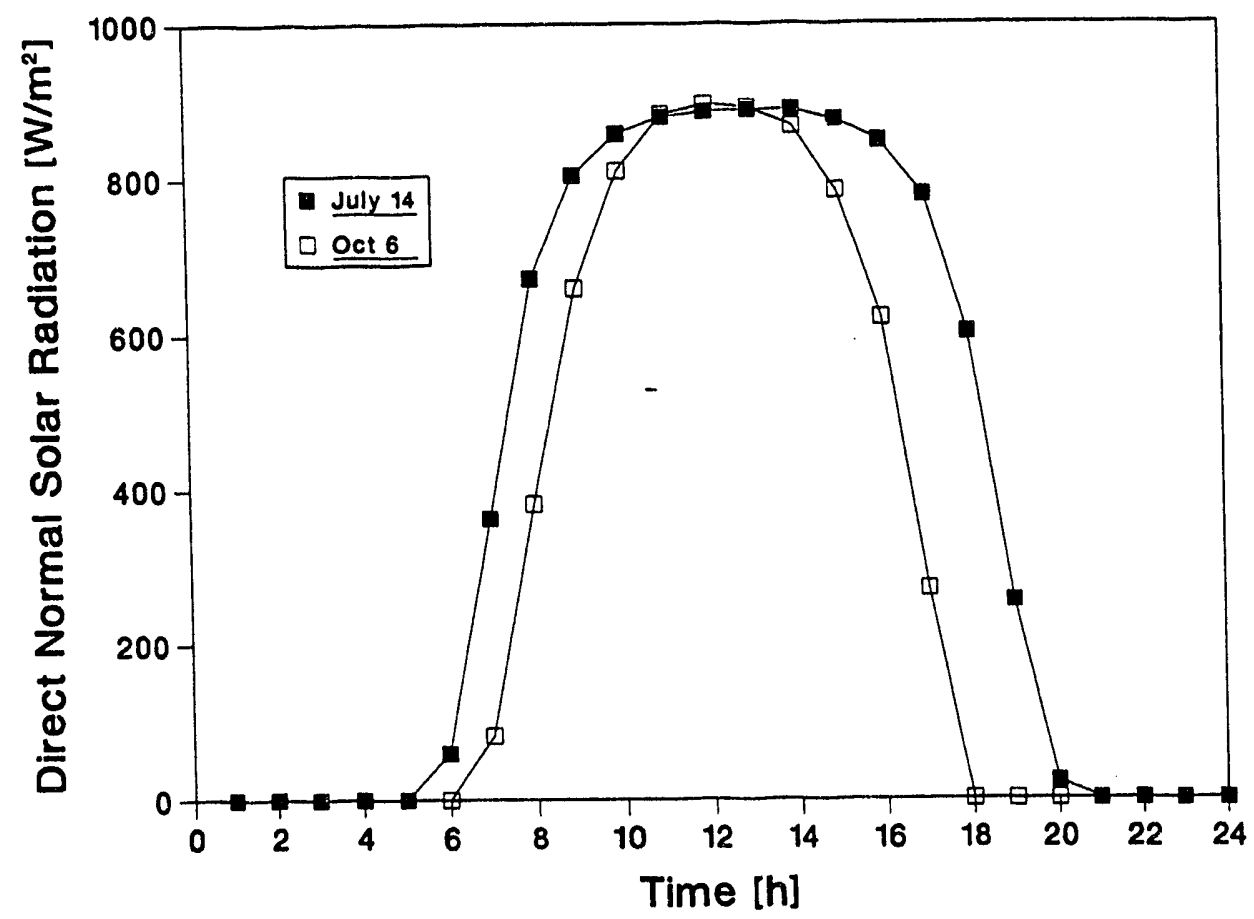

Figure 7b: Solar Radiation for Red Bluff, July 14 and October 6 


\begin{tabular}{|l|c|c|c|c|c|}
\hline \multicolumn{7}{|c|}{ Table 5a: Peak Load Components for modified Base-Case Building, } \\
\hline & Forth I & East I & South I & West I & Interior I \\
\hline & $7 / 14$ 5pm & $7 / 1511 \mathrm{am}$ & $10 / 63 \mathrm{pm}$ & $7 / 157 \mathrm{pm}$ & $12 / 185 \mathrm{pm}$ \\
\hline Cooling Date & 9 & 7 & 9 & 12 & 0 \\
\hline Walls & 0 & 0 & 0 & 0 & 0 \\
Roof & 20 & 12 & 6 & 15 & 0 \\
Glass Conduction & 19 & 23 & 30 & 25 & 0 \\
Glass Solar & -0.7 & -0.7 & -0.5 & -0.7 & 0 \\
Underground Surf. & & 2 & 2 & 1 & 3 \\
Occupants to Space & 2 & 2 & 2 & 0 & 2 \\
sensible & 2 & 11 & 11 & 11 & 12 \\
latent & 12 & 4 & 4 & 4 & 5 \\
Light to Space & 4 & 0 & 0 & 3 & 0 \\
Equipment to Space & 0 & 60.7 & \\
Infiltration & 67.3 & 60.3 & 63.5 & 70.3 & 22.0 \\
\hline Total & & & & & \\
\hline
\end{tabular}

\begin{tabular}{|l|c|c|c|c|c|}
\hline \multicolumn{7}{|c|}{ Table 5b: Peak Load Components for modified Base-Case Building, } \\
Second Floor [W/m² floor area], Red Bluff \\
\hline & North II & East II & South II & West II & Interior II \\
\hline Cooling Date & $7 / 14$ 5pm & $7 / 151:$ im & $7 / 14$ 4pm & $7 / 157 \mathrm{pm}$ & $7 / 15$ 5pm \\
\hline Walls & 9 & 7 & 10 & 12 & 0 \\
Roof & 11 & 6 & 11 & 12 & 13 \\
Glass Conduction & 21 & 13 & 20 & 15 & 0 \\
Glass Solar & 21 & 26 & 15 & 28 & 0 \\
Door & 0 & 0 & 0 & 0 & 0 \\
Underground Surf. & 0 & 0 & 0 & 0 & 0 \\
Occupants to Space & 3 & 2 & 3 & 1 & 3 \\
sensible & 2 & 2 & 2 & 0 & 2 \\
latent & 12 & 11 & 11 & 10 & 13 \\
Light to Space & 4 & 4 & 4 & 4 & 5 \\
Equipment to Space & 0 & 0 & 0 & 3 & 0 \\
Infiltration & 83.0 & 71.0 & 76.0 & 85.0 & 35.8 \\
\hline Total & &
\end{tabular}

As Table 4 shows, the largest amount of heat enters the zones through the windows. Up to $122 \mathrm{~W} / \mathrm{m}^{2}$ of floor area are transmitted into the south zone. This corresponds to almost $70 \%$ of the overall cooling load. It seems to be clear that measures have to be taken to avoid such a high solar gain. Although, solar gain is the primary source of heat load in the south zone, even the north zone accumulates more than $100 \mathrm{~W} / \mathrm{m}^{2}$. 
Whereas the driving source for the cooling load for the south zone is the solar gain, the load for the north zone is dominated by heat transfer caused by high outside temperatures. This is indicated by the time of the peak load shown in Table 5. Not only the hour of the peak is different between the zones, but also the days. Whereas the south zone has it's peak in October, all other perimeter zones experience their peak in July. In order to understand this peak shift phenomenon, ambient temperatures and solar radiation are plotted in Figure 7 for the two days. Solar radiation reaches approximately $900 \mathrm{~W} / \mathrm{m}^{2}$, but outdoor temperatures and the shape of the solar radiation curves are significantly different. Whereas the temperature on the 6 th of October stays below $40^{\circ} \mathrm{C}$, this value is already reached at 10 o'clock on the 14 th of July.

The building components for the base-case building have been varied in a parametric study to find the combination of components which help to reduce the cooling load to reasonable values (i.e., below $100 \mathrm{~W} / \mathrm{m}^{2}$ ). It should be reported that, with triple reflecting glass, doubling the roof insulation level, vented luminaires and a reduction of the lighting power, cooling loads below $60 \mathrm{~W} / \mathrm{m}^{2}$ are possible. However, even smaller changes help to reduce the cooling load significantly.

The specific loads $f(\pi$ individual building components at zone peak power are listed in Tables 5a) and b). To reduce specific peak loads below $100 \mathrm{~W} / \mathrm{m}^{2}$ floor area double glazed windows with reflective coating for East, South and West zones have been used. Insulation levels for the roof have been tripled to reduce the heat flux through the flat roof. These changes reduce solar radiation gain at zone peak power to $30 \mathrm{~W} / \mathrm{m}^{2}$ and keeps the influence of the roof below $15 \mathrm{~W} / \mathrm{m}^{2}$. The highest peaks are experienced in the West and the North (!) zones; but the less than $90 \mathrm{~W} / \mathrm{m}^{2}$ load can be handled by the radiant cooling system (see Section "Cooling Power).

\section{Energy Savings}

The use of radiant cooling systems is an energy conserving and peak-power reducing alternative to conventional air-conditioning which is particularly suited to dry climates. A significant amount of electrical energy used to cool buildings by All-Air Systems is drawn by fans which are used to transport cool air through the ducts. Part of this electricity used to move the air is heating the conditioned air, and therefore, is part of the internal thermal cooling peak load. The electrical cooling peak load, if defined as the load of the fans and the chillers, can be divided approximately into $37 \%$ for running the fans and $63 \%$ for using the chillers.

If ventilation and thermal conditioning of buildings are separated, the amount of air transported through buildings could be reduced significantly. In this case the cooling would to be provided by radiation using water as the transport medium. The ventilation has to be provided by outside air systems without the recirculating air fraction. Due to the physical properties of water, radiant cooling systems can remove a given amount of thermal energy using less than 5\% of the otherwise necessary fan energy. Although the supply air necessary for ventilation purposes will still be distributed through ducts, the electrical energy for transportation (air and water) can be reduced to approximately $25 \%$ 
of the original number.

The elimination of recirculation air also increases the efficiency of air-handling luminaires, as the convective heat extracted from the light fixtures is not recirculated as it would be in an All-Air-System but vented directly to the ontside. 50\% of the thermal cooling energy due to lighting can be removed this way. Compared to a constant volume air system an overall electrical cooling energy savings potential of more than $40 \%$ seems reasonable (see Figure 8).

\section{Peak-Power Requirement}

In order to compare the electrical peak-power requirement for conventional systems (All-Air-Systems) and advanced systems (Air-and-Water Systems), the power requirement for a simple example has been calculated.

The example is based on an office with a floor area of $25 \mathrm{~m}^{2}$, a two person occupancy and a total heat gain of $2000 \mathrm{~W}$. The specific cooling load amounts to $80 \mathrm{~W} / \mathrm{m}^{2}$, which is in the range of radiant cooling systems. Tine room temperature is set to $26^{\circ} \mathrm{C}$. Additional assumptions and design considerations used for this example are shown in Table 6.

The operation of an All-Air-System and an Air-and-Water-System can be seen in Figures 8 and 9. -

The All-Air-System supplies the cooling to the room as follows: the outside air is treated by a cooler which dehumidifies the air according to the required room condition. ASHRAE Standard 62 (ASHRAE 1989) requests a minimum air change rate of $36 \mathrm{~m}^{3} / \mathrm{h}$ Person. This means that for this example the minimum air change rate is $72 \mathrm{~m}^{3} / \mathrm{h}$. In order to remove the internal load, a recirculating air volume flow of $678 \mathrm{~m}^{3} / \mathrm{h}$ is required. The assumed outside air condition of $32^{\circ} \mathrm{C}$ leads to a mixing temperature of $25.6^{\circ} \mathrm{C}$

After mixing, the air is treated by a cooling system. In order to adjust for the temperature increase due to the fan work, the air has to be cooled further down than the $18^{\circ} \mathrm{C}$ specified as supply air temperature. The temperature adjustment depends on the pressure drop, fan efficiency and volume flow. In our example the temperature rise has been assumed to be $1.0 \mathrm{~K}$.

The electrical power for an All-Air-System amounts in this example to:

$$
\Sigma_{\text {el_Alt-Air-System }}=1270 \mathrm{~W}
$$

In order to be able to compare the two systems the boundary conditions have to be equal. This includes the efficiencies of fans and motors, pressure losses for supply and exhaust ducts and chillers' COPs. 


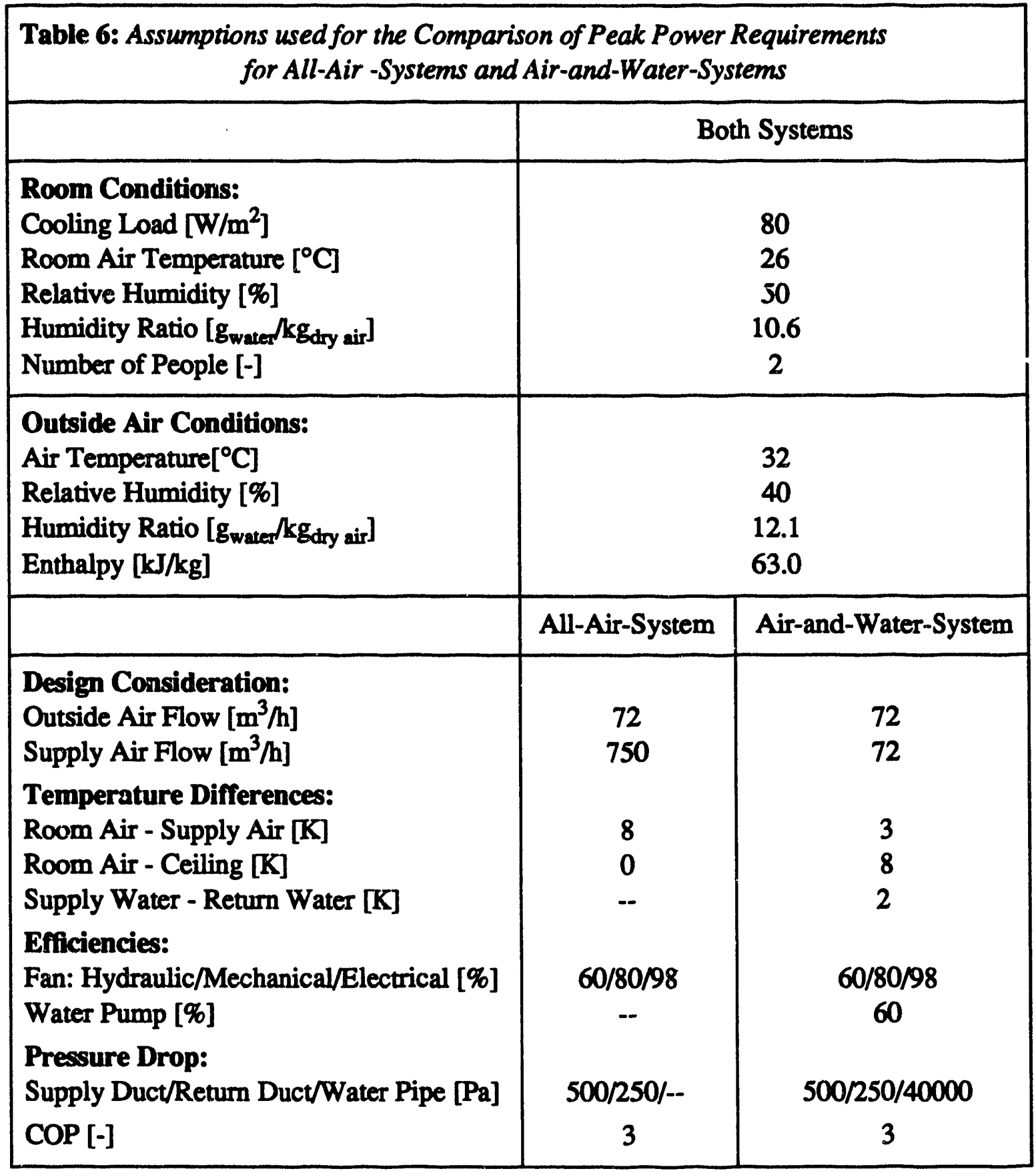

Whereas the All-Air-System removes the cooling load by means of supplying cold air, an Air-and-Water-System removes the load mainly by means of water. The air system's tasks thus are to supply the room with the necessary air exchange rate for hygienic reasons and to avoid humidity built up (control of the dew-point). In order to provide a stable displacement ventilation the supply air volume flow should be $3 \mathrm{~K}$ below room air temperature. Therefore the supply air temperature is reduced to $23^{\circ} \mathrm{C}$, which allows a reduction of the hydronic cooling load by $2.88 \mathrm{~W} / \mathrm{m}^{2}$. 


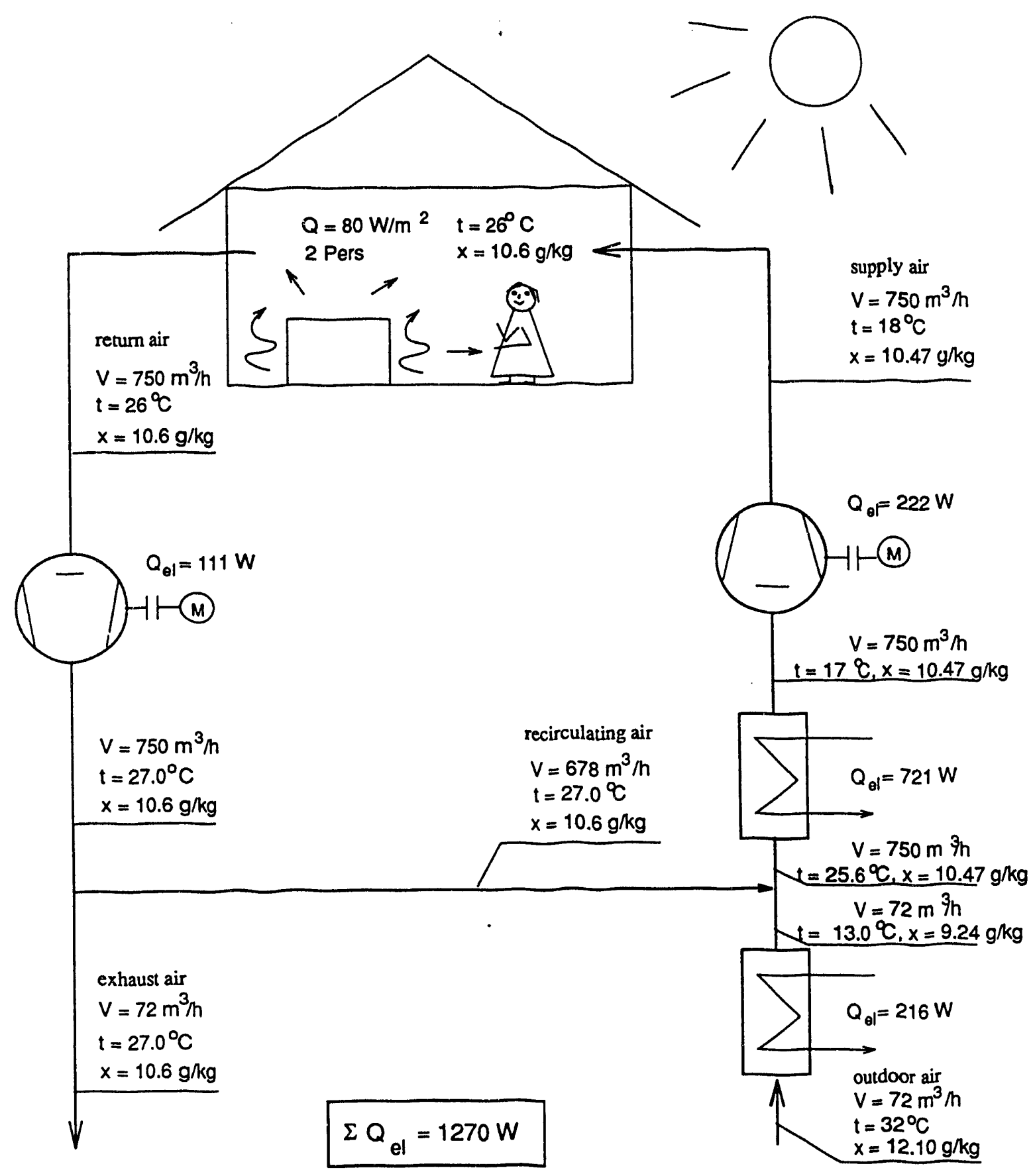

Figure 8: Peak Power Requirement for All-Air-Systems 


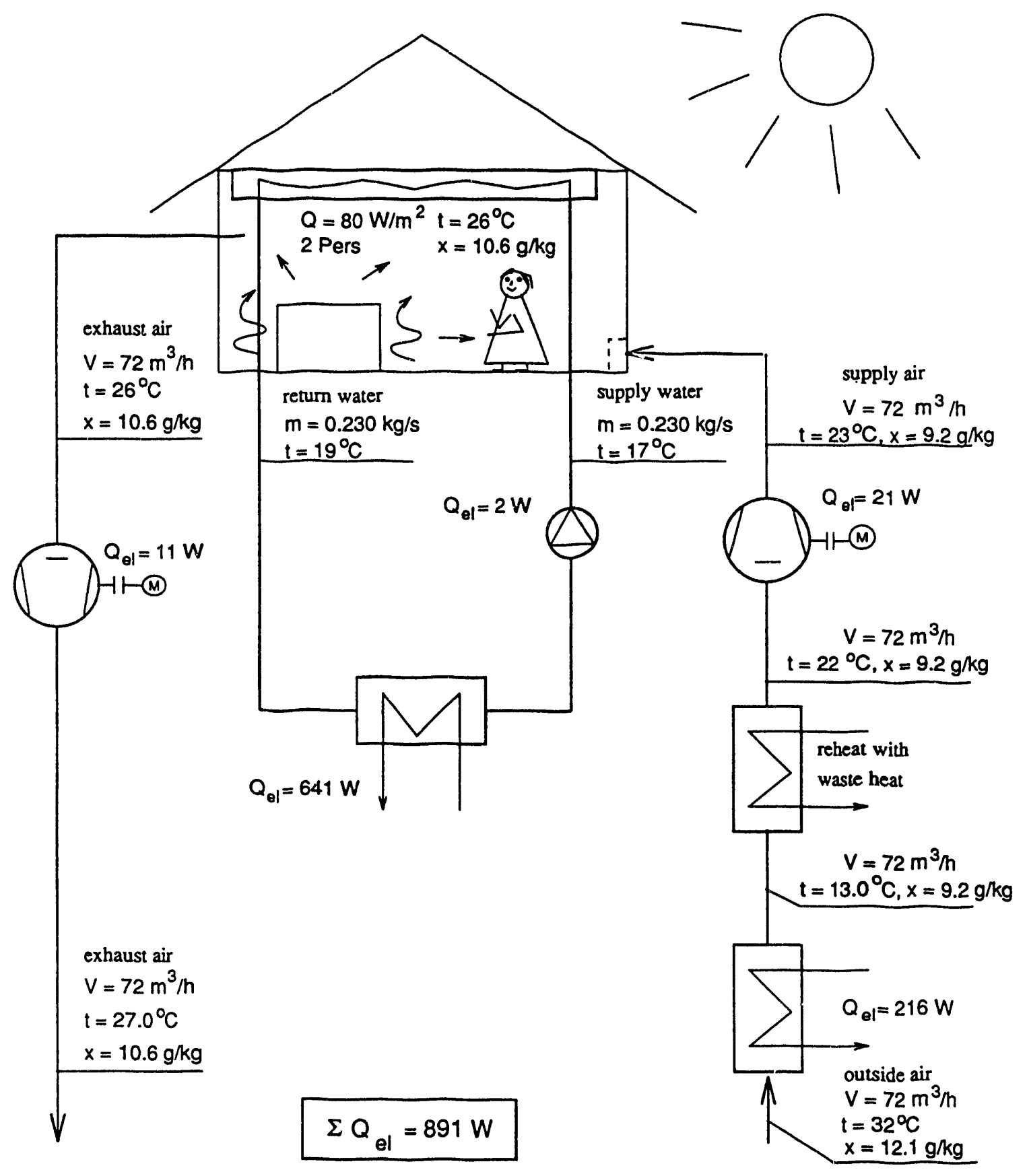

Figure 9: Peak Power Requirement for Air-and-Water-System 
In order to control humidity, the outside air might have to be cooled below the supply air temperature. A reheater is installed which increases the air temperature using waste heat from the compressor. A more efficient way to use the supplied cooling energy would be to channel the air through building components and provide some of the conditioning with the air. The electrical power of the Air-and-Water-System amounts to:

$$
\Sigma Q_{\text {ei,air+water }}=891 \mathrm{~W}
$$

Table 7 shows the electrical power calculated for an All-Air-System and an Air-andWater-System.

\begin{tabular}{|l|c|c|}
\hline \multicolumn{2}{|c|}{ Table 7: Electrical Power Requirement to remove Internal Loads } \\
\hline & All-Air-System & Air-and-Water-System \\
\hline \hline Supply Fan & $222 \mathrm{~W}$ & $21 \mathrm{~W}$ \\
Air Cooler & $721 \mathrm{~W}$ & -- \\
Pre-Cooler/Dehumidifier & $216 \mathrm{~W}$ & $216 \mathrm{~W}$ \\
Exhaust Fan & $111 \mathrm{~W}$ & $11 \mathrm{~W}$ \\
Water Pump & -- & $2 \mathrm{~W}$ \\
Water Cooler & -- & $641 \mathrm{~W}$ \\
\hline \hline Total & $1270 \mathrm{~W}$ & $891 \mathrm{~W}$ \\
& $100 \%$ & $70.2 \%$ \\
\hline
\end{tabular}

The Air-and-Warer-System has a power requirement of only about $70 \%$ of the total electrical powyer required by the All-Air-Systerin.

A comparison of electrical peak power requirement for All-Air-Systems and Air-andWater-Systems was performed based on the data shown in Table 7 [46]. Due to the higher specific cooling loads typicaliy found in office buildings, the peak power requirement for the Air-and-Water-Systein is reduced to appreximately 55\% of the requirement for All-Air-Systems (see Figure 10).

\section{Economics}

Although, manufacturers of hydronic radiant cooling systems claim many installations of their system, it is difficult to obtain information about econornics of the systems installed. Only few papers deal with the economics of hydronic cooling systems. Feil [45] compares different ventilation/cooling systems for an office. In first-cost comparison with a VAV-system, the break-even point for hydronic, systems is approximately at a specific cooling load of $55 \mathrm{~W} / \mathrm{m}^{2}$. Hoenmann and Nuessle [46] give yearly energy consumption for an office building in Europe (see Table 8). The building has $5000 \mathrm{~m}^{2}$ floor arei distributed over four floors. The specific cooling load is $50 \mathrm{~W} / \mathrm{m}^{2}$. 


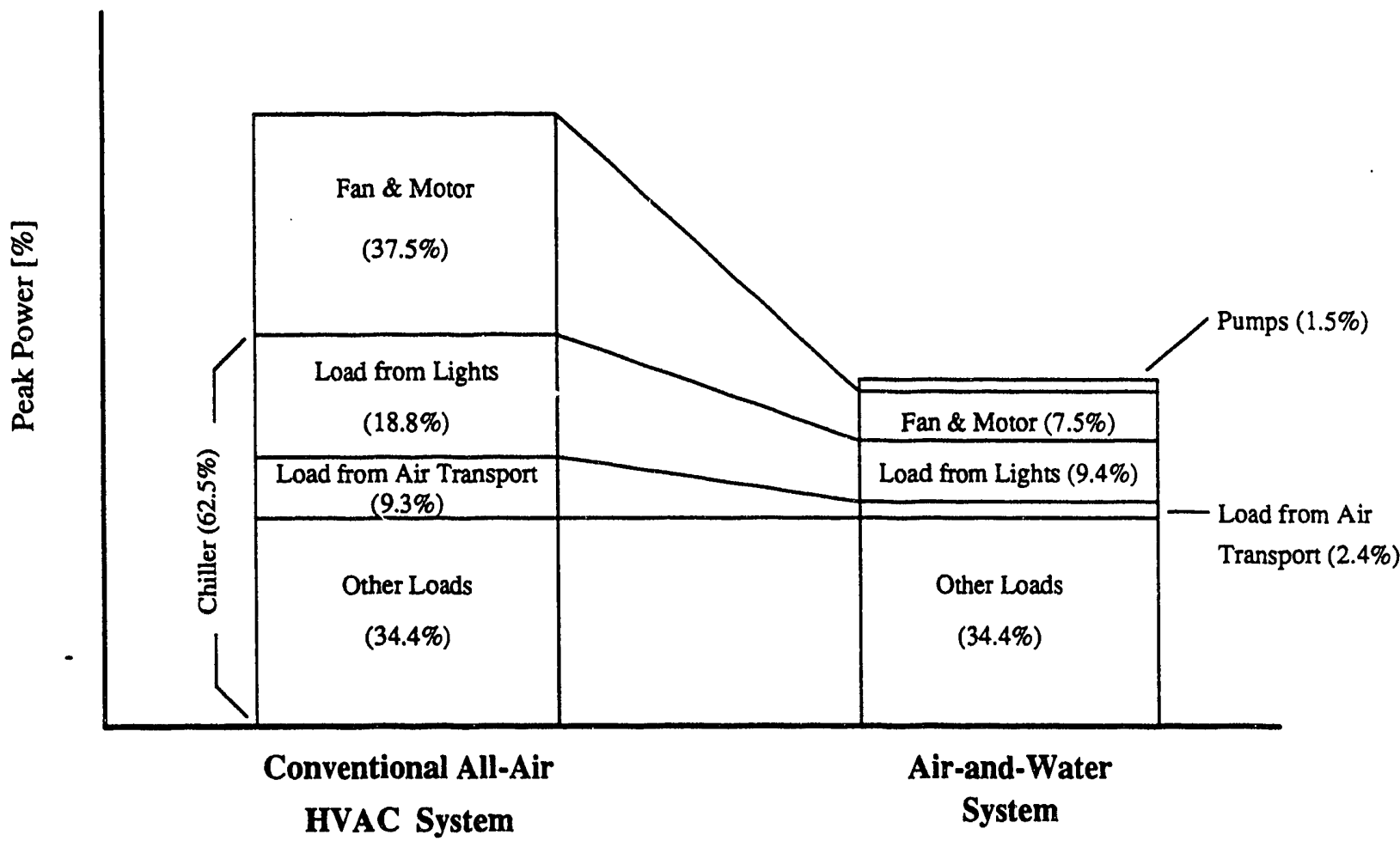

Figure 10: Comparison of Electrical Peak Power Load for All-Air Systems and Air-and-Water Systems. (For the Air-and-Water System, Percentages are relative to Overall Peak Power for the All-Air System)

The relatively low savings potential of less than $8 \%$ for the building's overall energy consumption is based on the large energy consumption due to heating and lighting. Unfortunately, the authors do not give consumption data for cooling only. Furthermore, the economizer mode savings potential utilized by the outside-air-only VAV-System has not been accomplished for the hydronic radiant system by installation of a watereconomizer.

The space requirement for the two systems are shown in Table 9. The biggest savings with $36 \%$ appear in the equipment rooms, followed by $28 \%$ for the distribution shafts. For systems with false ceilings, the reduction in height per floor calculates to 0.15 to 0.20 $\mathrm{m}$. Systems which are integrated into the ceiling produce higher savings. 


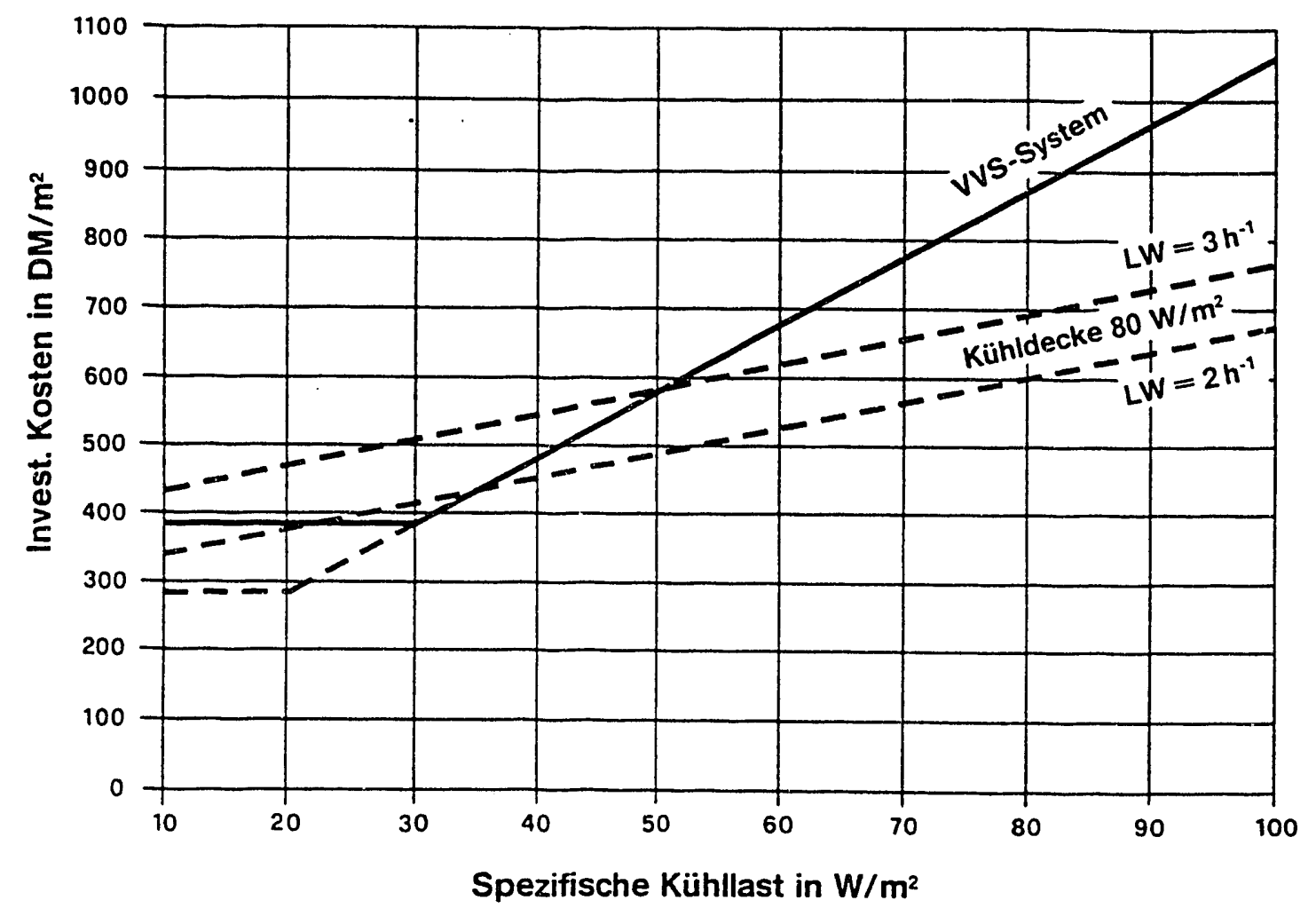

Figure 11: Comparison between First Cost for VAV-Systems and Hydronic Cooling Systems as a Function of the Specific Cooling Load [46], (VVS-System = VAV-System, Kuehldecke = Cooled Ceiling, $L W=$ Air Change per Hour, Invest. Kosten $=$ First Cost, Spezifische Kuehllast $=$ Specific Cooling Load)

For first cost calculations, Hoenmann et al. show a break-even point for their aluminium panel system at $50 \mathrm{~W} / \mathrm{m}^{2}$ if an air exchange rate of 3 ach is provided by the ventilation system (see Figure 11). 


\begin{tabular}{|l|c|c|}
\hline \multicolumn{3}{|c|}{ Table 8: Yearly Energy Consumption in $\mathrm{kWh} / \mathrm{m}^{2}$ for Office Building in Europe [46] } \\
\hline & VAV-System & Hydronic Cooling \\
\hline Heating & 43 & 43 \\
DHW & 4 & 4 \\
Lighting & 34 & 34 \\
Miscellaneous & 10 & 10 \\
Ventilation & 12 & 8 \\
Fans/Pumps & 31 & 24 \\
Cooling & 7 & 8 \\
\hline Sum & 141 & 131 \\
\hline
\end{tabular}

\begin{tabular}{|l|r|r|}
\hline \multicolumn{3}{|c|}{ Table 9: Space Requirements for Systems in Office Buildings [46] } \\
\hline & VAV-System & Hydronic Cooling \\
\hline Shafts & $25 \mathrm{~m}^{2}$ & $18 \mathrm{~m}^{2}$ \\
Equipment Rooms & $165 \mathrm{~m}^{2}$ & $107 \mathrm{~m}^{2}$ \\
Plenum Height & $0.4 \mathrm{~m}$ & $0.2 \mathrm{~m}$ \\
\hline
\end{tabular}

\section{Systems}

Most of the hydronic radiant cooling systems can be categorized by four different system designs. The system used most often is the panel system. This system uses aluminum panels with metal tubes connected to the rear of the panel (see Figure 12). Critical is the connection between the panel and the tube. Poor connections provide only limited heat exchange between the tube and the panel, which results in increased temperature differences between the panel surface and the cooling fluid. Panels build in a sandwich system, include the water flow paths beiween two aluminum panels (like the evaporator in a refrigerator). This arrangement reduces the heat transfer problem and increases the directly cooled panel surface.

Cooling registers formed out of small plastic tubes which are placed close to each other, can be imbedded in the plaster or mounted on ceiling panels (e.g., acoustic ceiling elements) (see Figure 13). This second system provides an equal surface temperature distribution. Due to the flexibility of the plastic tubes, this system might be the best choice for retrofit applications. This system has been developed in Germany and has been on the market for several years. 


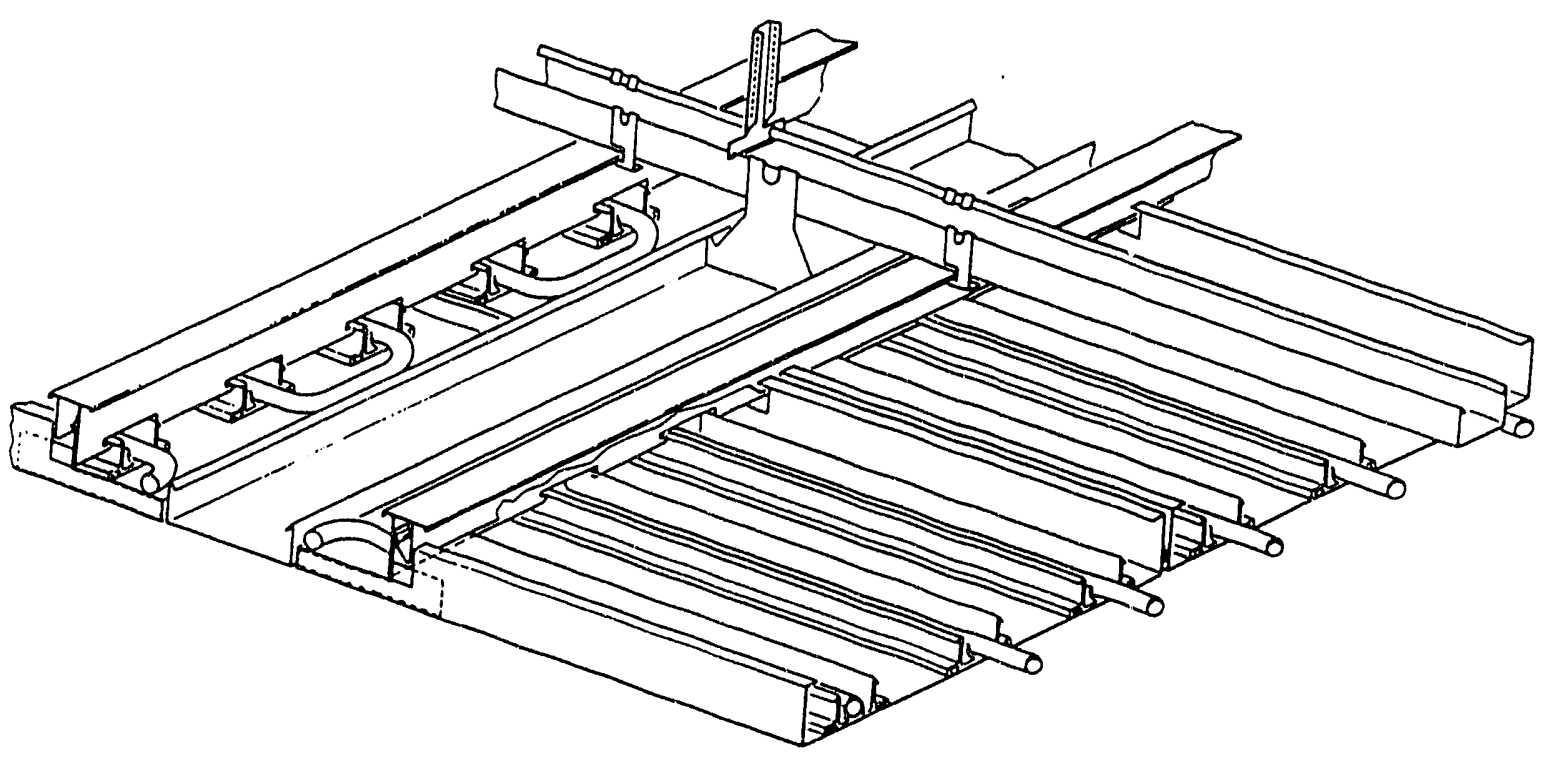

Figure 12: Construction of a Cooling Panel System [48]

The third system is based on the idea of a floor heating system. Tubes are imbedded in the core of a concrete ceiling. The thermal storage capacity of the ceiling allows for peak load shifting which provides the opportunity to use this system for alternative cooling sources. Due to the thermal storage involved control is limited. This leads to the requirement of relatively high surface temperatures to avoid uncomfortable conditions in the case of reduced cooling loads. The cooling power of the system is therefore limited [47]. This system is particularly suited for alternative cooling sources, especially the heat exchange with cold night air. The fast warming of rooms with a particular high thermal load can be avoided by running the circulation pump for short times during the day to achieve a balance with rooms with a lower thermal load. The DOW Chemicals European 


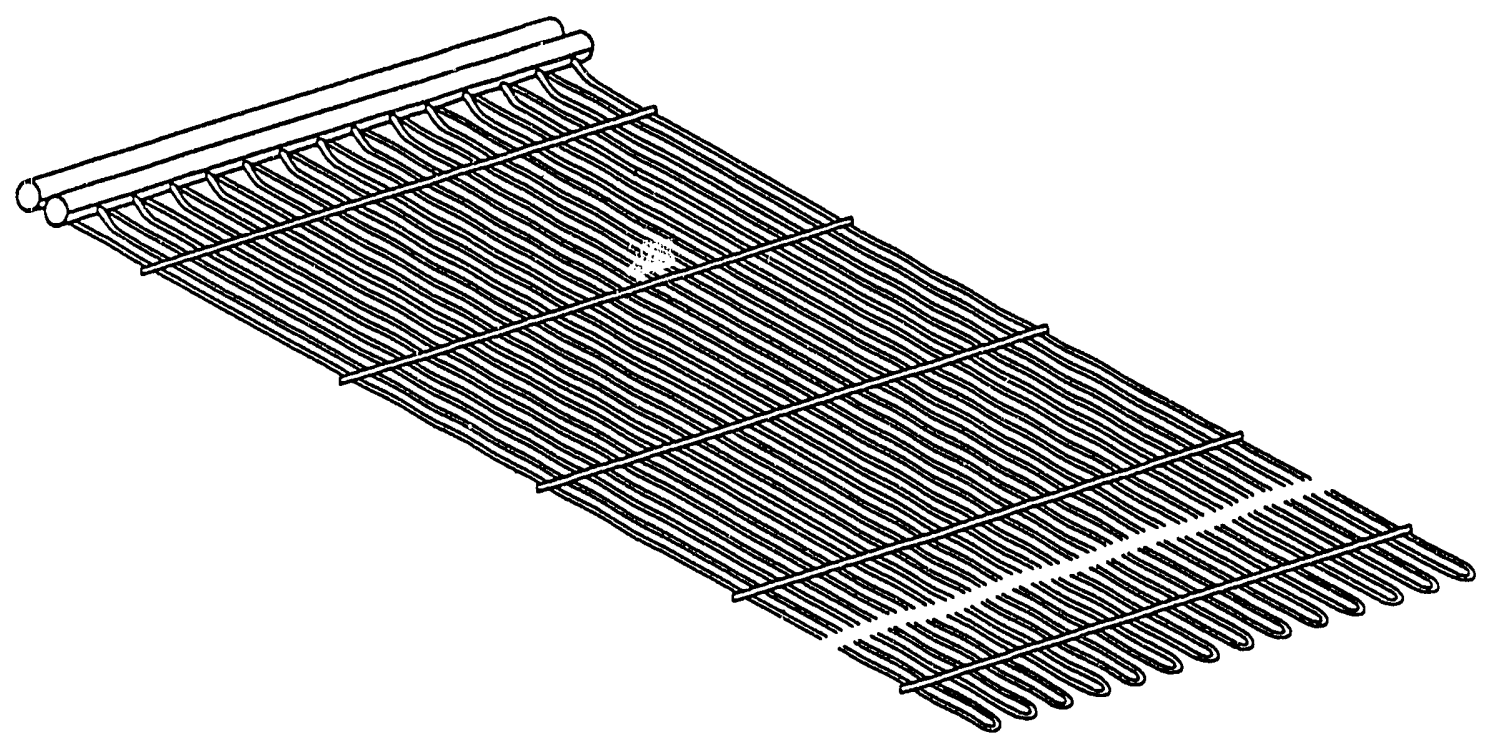

Figure 13: Construction of a Cooling Register [50]

headquarter in Switzerland is equipped with such a system.

A fourth system has also been developed in Germany, but is commercially available in California. It provides cooling to a raised floor. The floor provides space for the tubes and the supply plenum. Air is supplied below the windows; reducing the radiative effect of cold window surfaces in winter and hot window surfaces in summer [48].

The temperature profiles for the different ceiling panel systems have been published by Graeff [49]. 


\section{Control Issues}

As mentioned before, cooling power of radiative heat exchange is limited by the dewpoint of the room air. For safety reasons the cooling surface is kept above the dew-point for all operation conditions. In order to remove high thermal loads by means of radiation, one can manipulate the dew-point by dehumidifying the supply air. Consequently, the surface temperature of the cooled area can be reduced to increase the operative temperature difference. Precautions should be taken to keep within the specified comfort limits.

Besides the option to reduce the dew-point to avoid damage due to condensation, there is the possibility to switch off the supply of cold water as soon as the relative humidity reaches dangerous levels. Furthermore, buildings have been equipped with window contacts, cutting off the water supply when windows are opened and the ventilation system cannot guarantee trouble-free operation.

Temperature controls for different radiative cooling systems have very different response times. All systems working with thermal mass are relatively slow in response to load changes. If however, operation allows the room temperature to swing and cooling loads can be matched by these systems, they are the most energy efficient systems available. Systems with water supply close to the cooling surface and with little thermal mass (panel systems) have a response time comparable to All-Air-Systems.

Although, controlling the dew-point by dehumidifying the outside air requires lower cooler temperatures in the air handling system (than using outside air together with recirculation air for this task), the process is usually more energy efficient because of the smaller amount of air which has to be cooled before the dew-point is reached.

\section{Summary}

Whereas hydronic radiant cooling has been applied in the U.S., a significant market penetration was never reached. In Europe too, hydronic cooling was more or less abandoned after some applications in the late thirties and in the fifties. However, user complaints about All-Air Systems changed the designers' attitude towards these systems and have led to new system designs with better control. Together with efficient ventilation systems and humidity control, the hydronic radiant cooling system provides several advantages compared to conventional HVAC systems.

The reviewed literature shows that hydronic radiant systems provide draft-free cooling, reduce space requirements, increase indoor air quality, reduce the energy consumption for thermal distribution and for space conditioning, and might even have lower first-cost if specific cooling loads are above $55 \mathrm{~W} / \mathrm{m}^{2}$.

Unfortunately, literature has not been found describing the dynamic thermal behavior of the system and the building. The (dynamic) surface temperature distribution of the enclosure together with the air temperature determine the comfort temperature. Therefore, the dynamics might be an important parameter for further studies. As thermal building simulation programs do not provide the data necessary to judge the performance of radiant 
systems, development of dynamic models is needed to better understand comfort issues. Table 10 summarizes the features and their consequences of hydronic radiant cooling.

\begin{tabular}{|l|l|}
\hline \multicolumn{2}{|c|}{ Table 10: Summary of Hydronic Radiant Cooling Systems } \\
\hline \multicolumn{1}{|c|}{ Features } & \multicolumn{1}{c|}{ Effect } \\
\hline $\begin{array}{l}\text { Separate ventilation and } \\
\text { thermal conditioning }\end{array}$ & $\begin{array}{l}\text { Reduce air movement } \\
\text { Improve comfort }\end{array}$ \\
\hline $\begin{array}{l}\text { Transport cooling energy } \\
\text { by means of water }\end{array}$ & $\begin{array}{l}\text { Reduce transport energy } \\
\text { Reduce peak-power requirement }\end{array}$ \\
\hline Eliminate recirculation air & Improve Indoor Air Quality \\
\hline Use large cooling surfaces & Cool at high temperature level \\
\hline $\begin{array}{l}\text { Can utilize alternative } \\
\text { cooling sources }\end{array}$ & $\begin{array}{l}\text { Reduce energy consumption } \\
\text { Reduce peak-power requirement }\end{array}$ \\
\hline $\begin{array}{l}\text { Reduce size of thermal } \\
\text { distribution system }\end{array}$ & $\begin{array}{l}\text { Improve space usage } \\
\text { Reduce building cost }\end{array}$ \\
\hline Reduce convection & Improve comfort \\
\hline Limit cooling output & Need accurate sizing \\
\hline Increase risk of condensation & Need good humidity control \\
\hline
\end{tabular}

\section{Conclusions}

In Europe, hydronic radiant cooling became definitely an alternative to conventional AllAir Systems. Although, research results have been found supporting the claims made by manufacturers in Europe, there is not sufficient data available for US climates. An analysis based on typical US climates would be necessary to fully assess the applications of radiant cooling for other than the dry climates of California or Arizona.

Due to the availability of limited cooling power emphasis has to be on the building design focusing on the reduction of the building's cooling peak power requirement. A study should be performed, outlining the measures to be taken to satisfy the limited power for different California climates.

Current energy analysis programs, such as DOE-2, cannot simulate hydronic radiant cooling systems. As a result, there is no way to predict the expected performance, which inhibits their use. A computer model should be developed that allows users to calculate heat extraction rates and room surface temperature distributions for radiant cooling systems.

Several hydronic radiant cooling systems are already installed in California. There is some anecdotal evidence that some of these systems do not perform to the occupant's satisfaction. They either seem to consume more energy than predicted, or seem to have problems providing thermal comfort. These buildings should be studied to determine the 
status of the systems and to unveil the causes of the performance problems.

Performance test-methods should be developed to compare different products under standard conditions, and field tests should be performed showing the influence of climate, building design and room layout on hydronic radiant cooling performance.

As mentioned earlier, due to their relatively high temperature level, hydronic radiant cooling are obvious candidates to be mated with cooling sources other than compressors. Alternative cooling sources should be investigated to determine their energy savings potential, peak-power reduction and their interaction with the radiant cooling system.

\section{Acknowledgments}

The research reported here was funded by the California Institute for Energy Efficiency (CIEE), a research unit of the University of California. Publication of research results does not imply CIEE endorsement of or agreement with these findings, nor that of any CIEE sponsor.

This work was also supported by the Assistant Secretary for Conservation and Renewable Energy, Office of Buildings and Community Systems Building Systems Division of the U.S. Department of Energy under Contract No. DE-AC03-76SF00098.

\section{References}

1. Usibelli,A.; S. Greenberg; M. Meal; A. Mitchell; R. Johnson; G. Sweitzer; F. Rubinstein and D. Arasteh: "Commercial-Sector Conservation Technologies", Lawrence Berkeley Laboratory Report LBL-18543, 1985

2. Feustel, H.E.: "Economizer Rating" Final Report, prepared for Southern California Edison Company, 1989

3. 1987 ASHRAE Handbook, "Heating, Ventilating, and Air-Conditioning Systems and Applications", American Society of Heating, Refrigerating and AirConditioning Engineers, Inc., Atlanta, GA, 1987

4. Hoelzgen, J,: "Die Schwelle zur Zivilisation", Der Spiegel, (45), No. 33, pp. 160165, Spiegel Verlag, Hamburg, August 1991

5. Hottinger, M.: "Strahlungsheizung, Lueftung und Kuehlung in einem grossen Warenhaus", Gesundheitsingenieur 61 (1938), pp 129-134

6. Bradtke, F.: "Raumklimatische Fragen zur Deckenheizung"; GesundheitsIngenieur 61 (1938), pp 510-511 
7. Bilden, H.: "Bau und Betrieb der Strahlungsheizung und der Strahlungskuehlung", Heizung, Lueftung, Haustechnik 2 (1951), pp 5-9

8. Ronge, H.E. and B.E. Lofstedt: "Radiant Drafts from Cold Ceilings", Heating, Piping \& Air Conditioning (1957), No. 9, pp. 167-174

9. Baker, M.: "Improved Comfort through Radiant Heating and Cooling"; ASHRAE-Journal 2 (1960), No 2, pp 54-57

10. Boyar, R.: "Room Temperature Dynamics of Radiant Ceiling and AirConditioning Comfort Systems", ASHRAE-Transactions 69 (1963), pp37-45

11. Obrecht, M.F.; R.J. Salinger, and A. LaVanture: "Radiant Panel Ceilings", Heating, Piping, Air Conditioning (1973), No. 9, pp 55-62

12. Kroeling, P.: "Gesundheits- und Befindensstoerungen in klimatisierten Gebaeuden", Zuckschwerdt Verlag, Muenchen 1985

13. Fanger, P.O.: "Strategies to avoid Indoor Climate Complaints", In Proceedings "Third International Congress on Building Energy Management", ICBEM '87, Volume I, Presses Polytechnique Romandes, Lausanne, 1987

14. Mandell, M. and A.H. Smith: "Consistent Pattern of Elevated Symptoms in AirConditioned Office Buildings: A Reanalysis of Epidemiologic Studies", American Journal of Public Health, 80 (1990), No. 10

15. Esdorn, H., H. Knabl, R. Kuelpmann: "Air-Conditioning, New Horizons - New Opportunities", in Proceedings "Indoor Air '87", Berlin, 1987

16. Mayer, E.: "Thermische Behaglichkeit und Zugfreiheit, physiologische und physikalische Erkenntnisse", In Proceedings "XXII. Internationaler Kongress fuer Technische Gebaeudeausruestung", Berlin, 1988

17. Keller, G.M.: "Energieaufwand fuer den Luftransport mindern", Clima Commerce International, Vol. 21, No. 2, 1988

18. Skaret, E: "Displacement Ventilation", In Proceedings "Roomvent '87", Stockholm, June 1987

19. Sutcliff, H.: "A Guide to Air Change Efficiency", Technical Note AIVC TN 28, Air Infiltration and Ventilation Centre, Coventry, (1990)

20. Mathisen, H.M.: "Analysis and Evaluation of Displacement Ventilation", Division of Heating and Ventilation, NTH, NTH-Report No. 1989:31, Ph.D.-Thesis, 
1989

21. Cox, C.W.J.; P.J. Han;; J.M. Koppers and L.L.M. van Schijndel: "Displacement Ventilation Systems in Office Rooms - A Field Study", In Proceedings "Room Vent '90", Oslo, June 1990

22. Uschwa, H.: "Trendwende der Klimatechniker? "; Waermetechnik 6 (1989), pp 274-278

23. Anon.: "Loest die Strahlungsklimatisierung die Konvektionsklimatisierung ab ?"; Haustechnische Rundschau, Teil 1: 2 (1990), pp 74-76, Teil 2: 3 (1990), pp 120123

24. Diebschlag, W.: "Klimatische Behaglichkeit des Menschen innerhalb Raumumschliessungsflaechen mit unterschiedlich starker Reflexion von InfrarotWaermestrahlung"; Gesundheits-Ingenieur 3 (1985), pp 113-119

25. Recknagel, Sprenger : "Taschenbuch fuer Heizung und Klimatechnik"; Oldenbourg Verlag Muenchen, 1983/84, pp 35-39

26. Fanger, P.O.: "Thermal Comfort Analysis And Applications In Environmental Engineering", McGraw Hill, Inc., New York, NY, 1972

27. ASHRAE-STANDARD "Thermal Environmental Conditions for Human Occupancy"; ANSI-ASHRAE 55-1981, American Society of Heating, Refrigeration and Air-Conditioning Engineers,Inc., Atlanta, GA, 1981

28. McNall, P.E.,Biddison, R.E.: "Thermal and Comfort Sensations of Sedentary Persons Exposed to Asymmetric Radiant Fields"; ASHRAE-Transactions, Vol. 76, pp 123-136, 1970

29. Schlegel, J.C., McNall, P.E.: "The Effect of Asymmetric Radiation on the Thermal and Comfort Sensations of Sedentary Subjects"; ASHRAE-Transactions, Vol. 74, pp 144-154, 1968

30. Mayer, E.: "Auch die Turbulenzen sind wichtig", Clima Commerce International 19 (1985), No. 10, pp20

31. Mayer, E.: "Air Velocity and Thermal Comfort", in Proceedings "Indoor Air '87", Berlin, 1987

32. Kollmar, A.: "Die zulaessige Kuehldeckentemperatur aus waermephysiologischer Sicht", Gesundheits-Ingenieur 88 (1967), No. 5, pp 137-140 
33. Trogisch, A.: "Kuehldecke und Lueftung", Manuscript (1991) to be published at Clima Commerce International

34. Glueck: "Leistung von Kuehldecken," Kuehldecke und Raumluft, Fachinstitut Gebaeude-Klima, Stuttgart, 1990

35. Anon.: "SPC 138P, MOT for Rating Hydronic Radiant Ceiling Panels", Handout at the SPC138P-meeting on June 24, 1991, Indianapolis.

36. Anon.: "Radiant Metal Ceiling Panels - A Method of Testing Performance", Department of Veterans Affairs (Date unknown)

37. Kula, H.G.: "Theoretische Betrachtungen zur Kuehlung von Buerogebaeuden mit Aussenluft unter Beruecksichtigung der Speicherung und der Feuchtigkeitsentwicklung"; Diplomarbeit, 1989.

38. Anon: "Local Climatological Data - Annual Summaries for 1980," NOAA National Oceanic and Atmospheric Administration, Environmental Data and Information Service, National Climatic Center, Ashville, N.C., 1981

39. Kuelpmann, R. and H. Esdorn: "Thermische Behaglichkeit und Luftqualitaet in Raeumen mit Deckenkuehlung - Ergebnisse von Forschungsarbeiten", presented at the annual meeting of the Deutscher Kaeltetechnischer Verein, DKV, Heidelberg, 1990

40. Fanger, P.O., B.M. Ipsen, G. Langkilde, B.W. Olesen, N.K. Christensen, and S. Tanabe: "Comfort Limits for Asymmetric Thermal Radiation", Energy and Buildings, 8 (1985), pp 225-236

41. Esdorn, H. and M. Ittner: "Betriebsverhalten von Deckenkuehlsystemen", HLH Heizung- Lueftung- Haustechnik 41 (1990), pp.598-601

42. Esdorn, H. and M. Jakob: "Jahres-Betriebsverhalten eines Deckenkuehlsystems", HLH Heizung- Lueftung- Haustechnik 40 (1989), No.3, pp 149-152

43. Anon: "Compliance Options Approval Manual for the Building Energy Efficiency Standards," California Energy Commission, 1988

44. Anon: "DOE-2 Supplement, Version 2.1," Lawrence Berkeley Laboratory, LBLReport 8704, 1984

45. Feil, K.-H.: "Wirtschaftliche Betrachtungen zu Kuehldecken in Bueroraeumen", 
In: Kuehldecke und Raumlueftung, Fachinstitut Gebaeude-Klima e.V., Bietigheim-Bissingen, F.R.G., 1991

46. Hoenmann, W. and F. Nuessle: "Kuehldecken verbessern Raumklima", In: Kuehldecke und Raumlueftung, Fachinstitut Gebaeude-Klima e.V., BietigheimBissingen, F.R.G., 1991

47. Meierhans, R. and M. Zimmermann: "Slab Cooling and Earth Coupling", Proceedings Innovative Cooling Systems, International Energy Agency, Energy Conservation in Buildings and Community Systems, Solihull, U.K., May 1992

48. Anon: "Advanced Hydronic Heating and Cooling Technology", Leafiet, ehtSiegmund, Inc., Tustin, CA

49. Graeff, B.: "Kuehldecke und Raumklima", In: Kuehldecke und Raumlueftung, Fachinstitut Gebaeude-Klima e.V., Bietigheim-Bissingen, F.R.G., 1991

50. Anon: "The KA.RO Air Conditioning System from Herbst", Product Information Herbst Technik, Berlin, F.R.G., 1991 


\section{Appendix A: Cooling Power}

Radiant cooling elements extract heat from a room by cooling the air (convection) and by cooling the surfaces of the room's envelope. The two effects can be described by:

$$
q_{c}=\alpha_{c}\left[t_{\text {air }}-t_{\text {surface }}\right]
$$

for convection, and

$$
\mathrm{q}_{\mathrm{r}}=\zeta \mathrm{F}_{\mathrm{z}} \mathrm{F}_{\mathrm{e}}\left[\left[\frac{\mathrm{T}_{\mathrm{r}}}{100}\right]^{4}-\left[\frac{\mathrm{T}_{\mathrm{p}}}{100}\right]^{4}\right]
$$

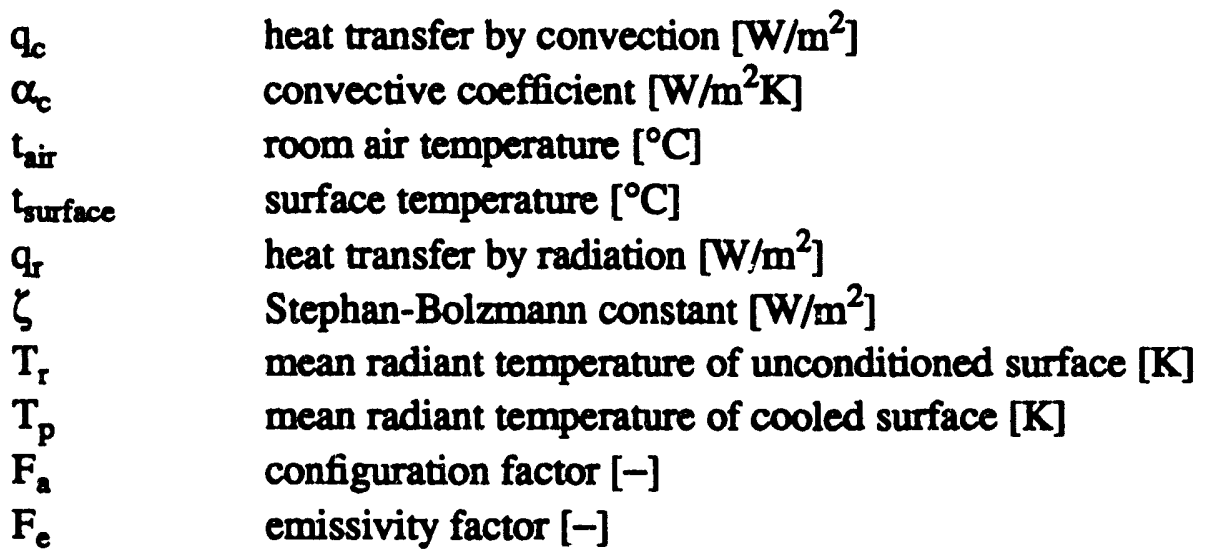

for radiation. This shows that the overall heat extraction is a function of the temperature differences between the cooling panel and the air as well as the different surfaces.

Both, convection and radiation, can be expressed by heat transfer coefficients. The combined heat transfer coefficient can be calculated using an empirical equation. Glueck (in [34]) developed the following equation based on measurements of cooled ceilings:

$$
\alpha_{\text {tot }}=8.92\left[t_{\text {air }}-t_{\text {surface }}\right]^{0.1}
$$

$\alpha_{\text {tot }}$

$$
\text { sum of convective and radiant heat coefficient }\left[\mathrm{W} / \mathrm{m}^{2} \mathrm{~K}\right]
$$

This empirical equation is based on the assumption that the mean surface temperature of the room differs only slightly from the air temperature. With this assumption, we can express the specific cooling power (per square meter) of a cooled ceiling by the following equation:

$$
\mathrm{q}_{\text {tot }}=8.92\left[\mathrm{t}_{\text {iir }}-t_{\text {surface }}\right]^{1.1}
$$

$q_{\text {tot }}$

sum of convective and radiant heat transfer $\left[\mathrm{W} / \mathrm{m}^{2}\right]$ 


\section{Appendix B: Climates used to determine Cooling Loads}

The climates used frit this study are described by a publication of the National Oceanic and Atmospheric Adirinistration as follows:

Arcata is located at the coast in northern California (Longitude $124.2^{\circ}$, Latitude $40.4^{\circ}$, Altitude $13 \mathrm{~m}$ ). The climate is complete $1 \mathrm{y}$ maritime with high humidity prevailing the entire year. Rainy season begins in October and continues through April. The dry season is marked by considerable fog or low cloudiness that usually clears in the late morning. Temperature as well as enthalpy, are below the conditions of indoor air most of the year.

Temperatures in Long Beach, California (Longitude $118.2^{\circ}$, Latitude $33.8^{\circ}$, Altitude 8 $\mathrm{m})$, rarely peak above $30^{\circ} \mathrm{C}$. The enthalpy only exceeds the indoor condition $(46.2$ $\mathrm{kJ} / \mathrm{kg}$ ), when the temperature is very high. Therefore, this climate can be described as moderately humid. The Pacific Dcean has also a moderating effect on temperatures. The Palos Verdes Hills form a natural border between the weather station and the sea; causing slightly greater ranges between minimum and maximum temperatures than stations on the immediate coast. Precipitation is sparse during the summer months. During the summer, low clouds are quite common in the late night and morning hours.

Red Bluff, California, is located in the northern end of the Sacramento Valley (Longitude $122.2^{\circ}$, Latitude $40.2^{\circ}$, Altitude $104 \mathrm{~m}$ ). Mountains surround the city on three sides, forming a huge horseshoe. The Coastal Range is located about 45 kilometers west, the Sierra Nevada about 60 kilometers east, and the Cascade Range about 75 kilometers northeast and north. Precipitation is confined mostly to rain during winter and spring months. Temperatures are highest during the months of June through September, when daytime readings frequently surpass the $35^{\circ} \mathrm{C}$ mark. Nighttime temperatures, however, are usually comfortable.

San Diego (Longitude $117.2^{\circ}$, Latitude $32.7^{\circ}$, Altitude $4 \mathrm{~m}$ ), is located in the southwest corner of southern California. Weather is tempered by the Pacific Ocein, with the result that summers are cooler and winters are warmer than other places along the same general latitude. Dry easterly winds sometimes blow in the vicinity for several days at a time, bringing temperatures above $30^{\circ} \mathrm{C}$. As on the rest of the Pacific Coast, a dominant characteristic of the spring and the summer is the nighttime and early morning cloudiness.

Lake Charles in Louisiana (Longitude $93.2^{\circ}$, Latitude $30.1^{\circ}$, Altitude $4 \mathrm{~m}$ ) is located on the lake of the same name and the Calcasieu River. Lake Charles' climate is humid subtropical with strong maritime character. The climate is influensed by the water surface provided by the lake, flooded rice fields and the Gulf of Mexico. Rainfall is substantial in all seasons. The absolute humidity rises with the seasonal rise of temperature, thus, the erithalpy increases more then proportionally to the temperature. The winter months are normaliy mild with cold spells usually of short duration. Summer relative humidity exceeds $80 \%$ for about 12 hours a day. 
